\title{
Climate change and ocean acidification impacts on lower trophic levels and the export of organic carbon to the deep ocean
}

\author{
A. Yool ${ }^{1}$, E. E. Popova ${ }^{1}$, A. C. Coward ${ }^{1}$, D. Bernie ${ }^{2}$, and T. R. Anderson ${ }^{1}$ \\ ${ }^{1}$ National Oceanography Centre, University of Southampton Waterfront Campus, European Way, Southampton SO14 3ZH, \\ UK \\ ${ }^{2}$ Met Office Hadley Centre, FitzRoy Road, Exeter EX1 3PB, UK
}

Correspondence to: A. Yool (axy@noc.ac.uk)

Received: 29 January 2013 - Published in Biogeosciences Discuss.: 25 February 2013

Revised: 18 July 2013 - Accepted: 19 July 2013 - Published: 5 September 2013

\begin{abstract}
Most future projections forecast significant and ongoing climate change during the 21 st century, but with the severity of impacts dependent on efforts to restrain or reorganise human activity to limit carbon dioxide $\left(\mathrm{CO}_{2}\right)$ emissions. A major sink for atmospheric $\mathrm{CO}_{2}$, and a key source of biological resources, the World Ocean is widely anticipated to undergo profound physical and - via ocean acidification - chemical changes as direct and indirect results of these emissions. Given strong biophysical coupling, the marine biota is also expected to experience strong changes in response to this anthropogenic forcing. Here we examine the large-scale response of ocean biogeochemistry to climate and acidification impacts during the 21 st century for Representative Concentration Pathways (RCPs) 2.6 and 8.5 using an intermediate complexity global ecosystem model, MEDUSA-2.0. The primary impact of future change lies in stratification-led declines in the availability of key nutrients in surface waters, which in turn leads to a global decrease (1990s vs. 2090s) in ocean productivity (-6.3\%). This impact has knock-on consequences for the abundance of the low trophic level biogeochemical actors modelled by MEDUSA$2.0(-5.8 \%)$, and these would be expected to similarly impact higher trophic level elements such as fisheries. Related impacts are found in the flux of organic material to seafloor communities $(-40.7 \%$ at $1000 \mathrm{~m})$, and in the volume of ocean suboxic zones $(+12.5 \%)$. A sensitivity analysis removing an acidification feedback on calcification finds that change in this process significantly impacts benthic communities, suggesting that a better understanding of the OAsensitivity of calcifying organisms, and their role in ballasting sinking organic carbon, may significantly improve fore-
\end{abstract}

casting of these ecosystems. For all processes, there is geographical variability in change - for instance, productivity declines $-21 \%$ in the Atlantic and increases $+59 \%$ in the Arctic - and changes are much more pronounced under RCP 8.5 than the RCP 2.6 scenario.

\section{Introduction}

Starting at the dawn of the industrial era, atmospheric concentrations of carbon dioxide $\left(\mathrm{CO}_{2}\right)$ have steadily increased from approximately $280 \mathrm{ppm}$ to almost $400 \mathrm{ppm}$, an absolute change that is greater than that between previous glacial and interglacial periods. This change has been driven largely by the combustion of so-called fossil fuels, but also by concomitant land-use changes and cement production. Many socioeconomic analyses forecast it to continue into the future, with some scenarios of future human impact elevating $\mathrm{CO}_{2}$ to almost 1000 ppm by the close of the current century (Houghton et al., 2001).

Nonetheless, rising atmospheric $\mathrm{CO}_{2}$ is already mitigated by a suite of earth system processes, on both land and in the ocean, that act to remove anthropogenic $\mathrm{CO}_{2}$ to these reservoirs. In the case of the land, this is largely believed to be driven by the "fertilisation effect" that elevated atmospheric $p \mathrm{CO}_{2}$ has on terrestrial plants, which are able to fix $\mathrm{CO}_{2}$ at a lower cost in terms of water loss (Van Minnen et al., 2009). By contrast, uptake of anthropogenic $\mathrm{CO}_{2}$ by the ocean is believed to be driven by a series of physicochemical factors collectively referred to as the solubility pump. Here, elevated $\mathrm{CO}_{2}$ dissolution in cold waters combines with 
deep water formation in the same locations to draw $\mathrm{CO}_{2}$ into the ocean's interior. It is estimated that this process has accounted for about $30 \%$ of the total anthropogenic emissions of $\mathrm{CO}_{2}$ (Sabine et al., 2004), although it is suggested by some workers that the strength of the ocean's solubility pump is in decline (Le Quéré et al., 2007).

Alongside the ocean's solubility pump is the so-called biological pump, which represents the sum of a series of biologically mediated processes that act to transport carbon - as organic carbon - into the ocean's interior. This pump is ultimately driven by the production of organic carbon by phytoplankton in the sunlit surface ocean and its subsequent aggregation into sinking particles (Volk and Hoffert, 1985; Buesseler et al., 2007). As dissolved inorganic carbon (DIC) is abundant in seawater, primary production in the ocean is not limited by $\mathrm{CO}_{2}$, but may instead be limited by the availability of nutrients such as nitrogen, silicon or iron (and by the activity of grazing zooplankton). As a result, the biological pump is not believed to have played any significant role in the ocean's response to anthropogenic $\mathrm{CO}_{2}$ to date (Gruber et al., 1996; but see also Boyce et al., 2010).

However, though the physical state of the ocean has changed only slightly since the start of the Industrial Revolution (cf. Levitus et al., 2005), future global warming is expected to cause significant changes to its stratification and circulation, with likely consequences for the biological pump (Van der Waal et al., 2010; Doney et al., 2012). An analysis of phytoplankton abundance (based on in situ and satellite observations) has suggested that change is already detectable and that they are declining in response to rising sea surface temperatures (Boyce et al., 2010, 2012; but see also Mackas, 2011; McQuatters-Gollop et al., 2011; Rykaczewski and Dunne, 2011; Boyce et al., 2011). And a number of modelling studies have found a similar relationship between increasing ocean stratification and declining ocean productivity and associated export (e.g. Bopp et al., 2001; Steinacher et al., 2010; but see also Taucher and Oschlies, 2011).

Related to oceanic uptake of anthropogenic $\mathrm{CO}_{2}$ is ongoing ocean acidification (OA). This occurs as the dissolved anthropogenic $\mathrm{CO}_{2}$ combines with $\mathrm{H}_{2} \mathrm{O}$ and speciates into bicarbonate and carbonate ions and protons. It is estimated that, since the start of the Industrial Revolution, surface ocean $\mathrm{pH}$ has declined from approximately 8.2 to 8.1 , an effective increase in acidity $\left(\left[\mathrm{H}^{+}\right]\right)$of $30 \%$ (Orr et al., 2005), and a comparable magnitude change is expected by 2050 depending upon future $\mathrm{CO}_{2}$ emissions (Orr et al., 2005). Furthermore, the longevity of significant change in ocean $\mathrm{pH}$ has been estimated at several hundred years, and extends far beyond the period of anthropogenic emissions of $\mathrm{CO}_{2}$ (e.g. Caldeira and Wickett, 2003).

There are a number of potential consequences of OA (Raven et al., 2005; Doney et al., 2009), but one that is believed significant is its impact on the solubility of the mineral calcium carbonate $\left(\mathrm{CaCO}_{3}\right)$. This is widely produced by marine organisms ranging across both the trophic- and size- spectra, from primary producers, such as coccolithophorids, through to heterotrophs, such as protistan foraminifera and metazoan pteropods. It is typically produced to form structures such as cell coverings, shells or skeletons, and occurs in two major crystal forms, calcite and aragonite, that differ in their solubility. As the ocean acidifies, carbonate chemistry shifts such that the concentration of bicarbonate increases, but that of carbonate decreases. As a result, the solubility of $\mathrm{CaCO}_{3}$ will increase, with potentially serious consequences for organisms using it for structural purposes (Orr et al., 2005; Fabry et al., 2008; Gangstø et al., 2011).

A more indirect impact of increased $\mathrm{CaCO}_{3}$ solubility may lie in its connection with the biological pump. Based on sediment trap observations, it has been hypothesised that the sinking flux of organic material to the deep ocean is enhanced in the presence of $\mathrm{CaCO}_{3}$, which acts to "protect" from remineralisation (Armstrong et al., 2002; Klaas and Archer, 2002). Should the abundance of calcifying organisms in the upper ocean decline in response to OA, this may shoal the remineralisation of organic material and diminish its flux into the abyssal ocean (Heinze, 2004). This may act to retain nutrients at shallower depths, but it may also act to decrease the food supply to seafloor communities reliant on sinking material.

Here we examine issues of future ocean productivity in response to climate change and OA using an intermediate complexity ecosystem model, MEDUSA-2.0. This model is used in simulations for the period 1860-2100 for two IPCC Representative Concentration Pathways (RCPs) of future $\mathrm{CO}_{2}$ concentrations (RCP 2.6 and RCP 8.5), and with sensitivity experiments to explore the impact of $\mathrm{OA}$ on $\mathrm{CaCO}_{3}$ production. The manuscript is structured as follows. First, MEDUSA-2.0 is briefly introduced, followed by a description of the simulation protocol. This is followed by an overview of the simulation's performance, both physically and biogeochemically, for the recent period (1980-2010). Next, results are presented for the 21st century, with a particular focus on the changes found between the 1990s and the 2090s. Most of the analysis deals with the higher $\mathrm{CO}_{2}$ pathway, RCP 8.5, but RCP 2.6 is also examined. The sensitivity of certain ecological processes such as export production to OA, through its connection to $\mathrm{CaCO}_{3}$ production, is also explored. Key questions examined are

- What are the sign and magnitude of changes in primary and export production driven by climate and OA change?

- How is calcification affected by OA change, and how does this impact organic carbon supply to the deep ocean?

This manuscript is concerned with changes to low trophic level actors and major biogeochemical processes at the global scale, with some intercomparison between major basins where behaviour differs geographically. This 
manuscript is complemented by a companion manuscript, Popova et al. (2013), that presents a more detailed analysis of the Arctic Ocean, the region of the World Ocean expected to be most affected by anthropogenic change.

\section{Methods}

\subsection{MEDUSA-2.0}

MEDUSA-2.0 is a size-based intermediate complexity ecosystem model that divides the plankton community into "small" and "large" portions, and which resolves the elemental cycles of nitrogen, silicon, iron, carbon, alkalinity and oxygen. Figure 1 shows a schematic diagram of the components of MEDUSA-2.0, together with the ecological links between them. The "small" portion of the ecosystem is intended to represent the microbial loop of picophytoplankton and microzooplankton, while the "large" portion covers microphytoplankton (specifically diatoms) and mesozooplankton. The intention of MEDUSA-2.0 is to separately represent small, fast-growing phytoplankton that are kept in check by similarly fast-growing protistan zooplankton, and large, slow-growing phytoplankton that are able to temporarily escape the control of slower-growing metazoan zooplankton. The nonliving particulate detritus pool is similarly split between small, slow-sinking particles that are simulated explicitly, and large, fast-sinking particles that are represented only implicitly. Within MEDUSA-2.0, phytoplankton growth and slow-sinking detritus remineralisation are temperaturedependent, with both exhibiting higher rates at warmer ambient temperatures (following Eppley, 1972). The aim of MEDUSA-2.0 is to represent major biogeochemical processes in the World Ocean that are well understood, and to do so with a minimal number of model components to reduce computational costs.

MEDUSA-2.0 resolves 15 state variables distributed between the nitrogen (6), silicon (2), iron (1), carbon (2), alkalinity (1) and oxygen (1) cycles. The remaining two state variables denote chlorophyll for each of the model's two phytoplankton classes. Because of its key role in organising marine productivity, nitrogen is MEDUSA-2.0's primary currency. For simplicity, MEDUSA-2.0 assumes fixed $\mathrm{C}: \mathrm{N}$ ratios for the plankton pools (phytoplankton, zooplankton), but allows these to have different $\mathrm{C}: \mathrm{N}$ ratios (e.g. zooplankton are assumed to have a lower ratio; Anderson, 2005). This variable stoichiometry is accounted for in the flow of organic material to detrital pools, where both slow- and fast-sinking particulate organic material $(\mathrm{POM})$ have variable $\mathrm{C}: \mathrm{N}$ ratios depending upon the processes (plankton mortality, zooplankton egestion) that contribute to them. Note, however, that MEDUSA-2.0 omits the possibility of a dynamic response of phytoplankton $\mathrm{C}: \mathrm{N}$ ratio (and, thus, organic carbon production) to increases in the oceanic concentration of DIC (Riebesell et al., 2007). Though model diatoms have a

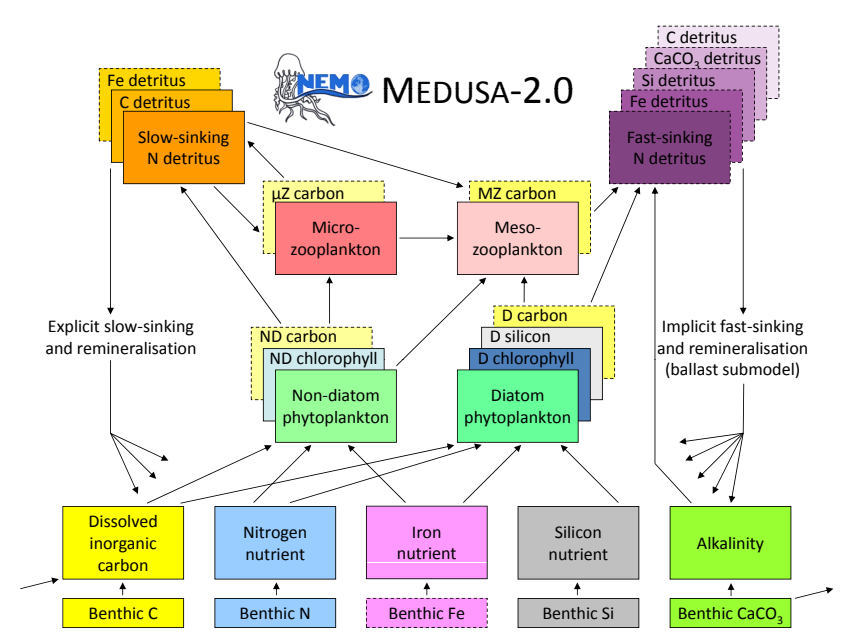

Fig. 1. Schematic diagram of the components and interactions in the MEDUSA-2.0 model. Boxes with solid borders indicate explicitly modelled state variables, while boxes with dashed borders indicate implicitly modelled components. Overlapping boxes indicate components for which multiple currencies are modelled (e.g. different elements, chlorophyll). The smaller boxes at the bottom of the diagram refer to benthic reservoirs of model currencies that are fed by sinking detrital material (slow- and fast-sinking). Note that the dissolution of benthic $\mathrm{CaCO}_{3}$ releases both DIC and alkalinity.

fixed $\mathrm{C}: \mathrm{N}$ ratio, MEDUSA-2.0 includes a separate state variable for diatom opal, allowing a dynamic $\mathrm{Si}: \mathrm{N}$ ratio. This allows MEDUSA-2.0 to reflect known diatom responses to the availability of silicic acid and other nutrients (Mongin et al., 2006).

In addition to the state variables for the 3-D water column, 4 further state variables have been added to represent 2-D pools of organic and biogenic material at the seafloor. These pools permit temporary storage of particulate material before it is returned to dissolved pools, and they represent an extremely crude submodel of the benthic ecosystem.

Table A1 lists MEDUSA-2.0's state variables and their units. Appendix A lists the partial differential equations that describe MEDUSA-2.0. For further details, a full description of MEDUSA-2.0 can be found in Yool et al. (2013), with additional material from the description of its precursor, MEDUSA-1.0, in Yool et al. (2011). However, within the context of this study, MEDUSA-2.0's handling of $\mathrm{CaCO}_{3}$ production is relevant, and is expanded here.

This biomineral is used within shells and other structures of a wide range of pelagic organisms, including phytoplankton and zooplankton. However, the factors (physico-chemical and ecological) controlling its production are not fully understood (cf. Hood et al., 2006), and there is considerable diversity in the approaches taken to represent calcification in marine models (e.g. Tyrrell and Taylor, 1996; Moore et al., 2002; Gehlen et al., 2007; Ridgwell et al., 2007; Zahariev et al., 2008; Yool et al., 2010). Reviewing this, Kelly-Gerreyn et al. (2009) found no strong support for any one approach 
over its rivals, and in MEDUSA-1.0 (Yool et al., 2011), calcification was - via the rain ratio of $\mathrm{CaCO}_{3}: \mathrm{C}_{\text {org }}$ - made a simple function of latitude (partly following Dunne et al., 2007). Such a simplistic approach suited earlier work, but here the importance of OA and climate change favour a revised consideration.

In MEDUSA-2.0, calcification is instead calculated as a function of the ambient saturation state of the $\mathrm{CaCO}_{3}$ polymorph calcite, $f o\left(\Omega_{\text {calcite }}\right)$. This varies geographically (and in time), with

$$
f o\left(\Omega_{\text {calcite }}\right)=\left(\Omega_{\text {calcite }}-1\right)^{\eta} \cdot r_{0}
$$

where $f o\left(\Omega_{\text {calcite }}\right)$ is the rain ratio of fast-sinking detrital particles. This approach to calcification is based on the formulation of Ridgwell et al. (2007), and uses the concentrations of calcium (normalised to salinity) and carbonate (calculated from DIC) ions to calculate $\Omega_{\text {calcite. This term normalises }}$ $\mathrm{CaCO}_{3}$ saturation such that values greater than 1 denote supersaturation (i.e. $\mathrm{CaCO}_{3}$ insoluble), while values lower than 1 denote undersaturation (i.e. $\mathrm{CaCO}_{3}$ soluble). Parameters $\eta$ and $r_{0}$ then control the shape of this function (per Ridgwell et al., 2007). In MEDUSA-2.0 $\Omega_{\text {calcite }}$ is calculated locally (horizontally and vertically), and also dictates where the biomineral is dissolves in the water column. The total quantity of $\mathrm{CaCO}_{3}$ produced is the product of $f o\left(\Omega_{\text {calcite }}\right)$ and the production of such particles, in terms of $\mathrm{C}_{\text {org }}$. Note that, although calcite is used as the basis of calcification in MEDUSA-2.0, $\Omega_{\text {aragonite }}$ is also calculated as a diagnostic (see Sect. 3).

\subsection{Ocean physics}

The underlying physical model used in this work is version 3.2 of the Nucleus for European Modelling of the Ocean (NEMO; Madec, 2008). This is comprised of an ocean general circulation model, OPA9 (Madec et al., 1998; Madec, 2008), coupled with a sea-ice model, Louvain-la-Neuve Ice Model version 2 (LIM2; Timmermann et al., 2005). This physical framework is configured at approximately $1^{\circ} \times 1^{\circ}$ horizontal resolution $(292 \times 362$ grid points), with a focus on resolution around the equator to improve the representation of equatorial upwelling. Vertical space is divided into 64 levels, which increase in thickness with depth, from approximately $6 \mathrm{~m}$ at the surface to $250 \mathrm{~m}$ at $6000 \mathrm{~m}$. To improve the representation of deep water circulation, partial level thicknesses are used in the specification of bottom topography. Vertical mixing is parameterised using the turbulent kinetic energy (TKE) scheme of Gaspar et al. (1990), with modifications by Madec (2008).

The sea-ice submodel used here, LIM2, is based upon viscous-plastic ice rheology (Hibler, 1979) and three layer (two layers of sea ice, one layer of snow) thermodynamics (Semtner, 1976), with a number of updated physical processes (see Timmermann et al., 2005; and references therein). Model sea ice is coupled to the ocean every 5 ocean time steps through the non-linear quadratic drag law of the shear between sea-ice and ocean surface velocity (Timmermann et al., 2005). Freshwater exchange between the ocean and sea ice is calculated from precipitation and ice formation/melting (Fichefet and Morales Maqueda, 1997), where sea-ice salinity is assumed to be 4 psu and rain/snow are assumed fresh. The heat flux between the sea ice and ocean is proportional to the departure in temperature from salinity-dependent freezing point and the friction velocity at the ice-ocean interface. Solar radiation can penetrate sea ice not covered by snow, and is dissipated by brine pockets within the ice where it increases latent heat storage (Fichefet and Morales Maqueda, 1997).

\subsection{Surface forcing}

In Yool et al. (2011), NEMO was forced at the ocean surface for the period 1966-2005 using DFS4.1 fields developed by the European DRAKKAR collaboration (DRAKKAR Group, 2007). As MEDUSA-2.0 includes the ocean's carbon cycle, and since this is currently undergoing secular change driven by increasing atmospheric concentrations of $\mathrm{CO}_{2}$, simulations running over a longer period of time are necessary. There are a number of approaches to achieve this including, for instance, the use of a climatological average or "normal year" (e.g. Najjar et al., 2007), or the repeated cycling of historical forcing (e.g. Yool et al., 2010). These have the advantage of using actual observationally derived forcing, but also assume that the recent past from which they are derived is representative of earlier periods of time (in spite of ongoing climate change). An alternative approach is to utilise forcing derived from either atmospheric models or coupled ocean-atmosphere models. These are routinely run in long duration simulations that span pre-industrial or pre-20th century periods when there was comparatively little change in climate or the carbon cycle. They also offer the opportunity to forecast biogeochemical cycles into the future with a significantly different climate from that of the present day.

Here, NEMO is forced following this latter approach, using output from a simulation of the HadGEM2-ES Earth system model developed by the UK Meteorological Office (UKMO). HadGEM2-ES comprises underlying physical atmosphere and ocean components with representations of the terrestrial and oceanic carbon cycles, and tropospheric chemistry and aerosols (Collins et al., 2011). The simulations used here were performed as part of the UKMO's input to the Coupled Model Intercomparison Project 5 (CMIP5) (Jones et al., 2011) and Assessment Report 5 (AR5) of the Intergovernmental Panel on Climate Change (IPCC). HadGEM2-ES output was processed into the same forcing fields as that provided by the DFS4.1 forcing previously used with MEDUSA-1.0. The frequency of the output fields also matched that of DFS4.1, i.e. monthly for precipitation (rain, snow, runoff), daily for radiation (downwelling shortand long-wave) and 6-hourly for the turbulent variables (air 
temperature, humidity and wind velocities). Note that the reference height of forcing in HadGEM2-ES differs from that of DFS4.1, but that NEMO's bulk formulae allow this height to readily be changed to accommodate HadGEM2-ES.

\subsection{Initialisation}

For maximum congruence with the surface forcing, temperature and salinity fields are initialised here using output from HadGEM2-ES valid for the same time as the forcing. To prevent excessive drift, sea surface salinity (SSS) is relaxed towards that derived from HadGEM2-ES. Unlike simulations under DFS4.1, where an invariant monthly mean climatology of SSS values is used, here the SSS target consists of a monthly time series running across the forcing period. The relaxation timescale is approximately 30 days for the open ocean, and 12 days under sea ice. The freshwater budget is also monitored for imbalances between integrated downward and upward fluxes, and a correction term applied between years (i.e. an imbalance in year $X$ is corrected for in year $X+1)$.

MEDUSA-2.0's fields of DIN, silicic acid and oxygen were initialised using January values from the World Ocean Atlas 2009 (Garcia et al., 2010a). Similarly to MEDUSA1.0, total iron was initialised using an iron field derived from a long-duration simulation of a lower resolution GCM (Parekh et al., 2005; Dutkiewicz et al., 2005). DIC and alkalinity were initialised using the GLODAP climatology (Key et al., 2004). It was assumed that GLODAP's pre-industrial DIC field is approximately valid for the 1860 start of this simulation, though this approach has known issues concerning the ocean's anthropogenic $\mathrm{CO}_{2}$ inventory in 1860 (e.g. Yool et al., 2010). Note that the GLODAP fields used here required modification to account for large regional lacunae such as the Arctic Ocean. This was achieved using a series of localised multiple linear regressions (MLRs) derived using World Ocean Atlas (WOA) and Global Ocean Data Analysis Project (GLODAP) values from adjacent regions - see Yool et al. (2013) for a description of the procedure.

\subsection{Simulation}

The configuration of NEMO-MEDUSA-2.0 described above was simulated from 1860 through 2005. In 2005 two separate simulations were initialised from the model's state to follow either the RCP 2.6 or RCP $8.5 \mathrm{CO}_{2}$ pathways to the end of 2099. Figure 2 shows the atmospheric $p \mathrm{CO}_{2}$ in these scenarios, together with the resulting globally averaged surface air temperatures (as simulated in HadGEM2-ES). Surface air temperatures increase by around $1.5^{\circ} \mathrm{C}$ through the next century in RCP 2.6, with $\mathrm{CO}_{2}$ concentrations increasing by around $50 \mathrm{ppm}$. Temperatures are broadly stable from 2050 onwards. RCP 8.5 , by contrast, sees increases in $\mathrm{CO}_{2}$ concentration of over $500 \mathrm{ppm}$ and warming of $5^{\circ} \mathrm{C}$ with temperatures increasing rapidly by 2100 .
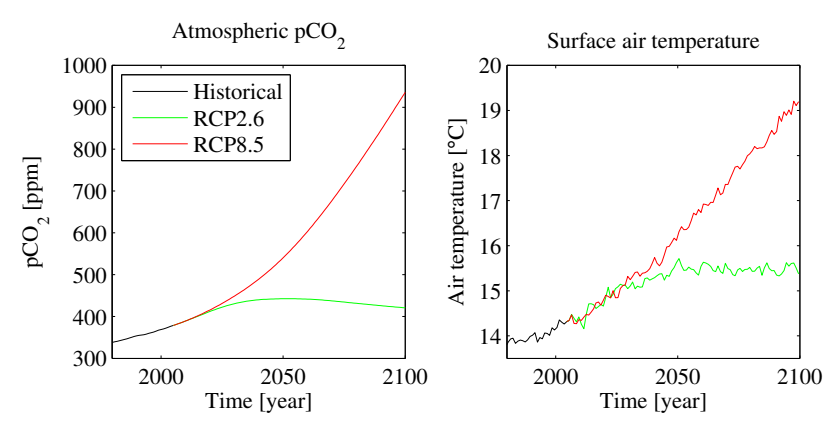

Fig. 2. The left panel shows atmospheric $p \mathrm{CO}_{2}$ concentrations for the historical period (black; 1860-2005), RCP 2.6 (green; 20052100) and RCP 8.5 (red; 2005-2100). The right panel shows global average surface air temperature simulated for the same period.

\section{Results}

\subsection{Validation}

This subsection presents a brief overview of the performance of both NEMO and MEDUSA-2.0 in recent decades for the purposes of validation and to illustrate the "ground state" against which change occurs. A more thorough overview of MEDUSA-2.0's performance can be found in Yool et al. (2013), including an intercomparison with comparable biogeochemical models from the CMIP5 archive.

Figure 3 shows an intercomparison of simulated, globally averaged sea surface temperature (SST) and total Arctic seaice area (= grid cell area $\times$ fractional ice cover) with that from the Hadley Centre Sea Ice and Sea Surface Temperature (HadISST) observational dataset for the period 1980 to 2009 (inclusive). In the case of both plots, the solid lines indicate annual average, while the shaded regions denote the extent of monthly ranges for both properties. While the patterns of interannual variability in SST are clearly not identical between observations and the model, the long-term warming trend is comparable, though the model tends to show a slightly broader monthly range. Similarly with Arctic sea-ice trends, though the model tends to systematically overestimate seaice area.

Figure 4 shows corresponding geographical plots of SST for June-July-August (JJA) and December-January-February (DJF), averaged in this case for the period 2000-2009. While there is considerable, and unsurprising, congruence between the observations and model, there are also noticeable differences. For instance, the Peruvian and Benguelan upwelling regions - demarcated by lower temperatures - are much less pronounced in NEMO. Also, the position of the Gulf Stream in the North Atlantic is clearly shifted eastwards in the model relative to observations, and Southern Ocean waters are marginally warmer in NEMO than in the HadISST observations. 

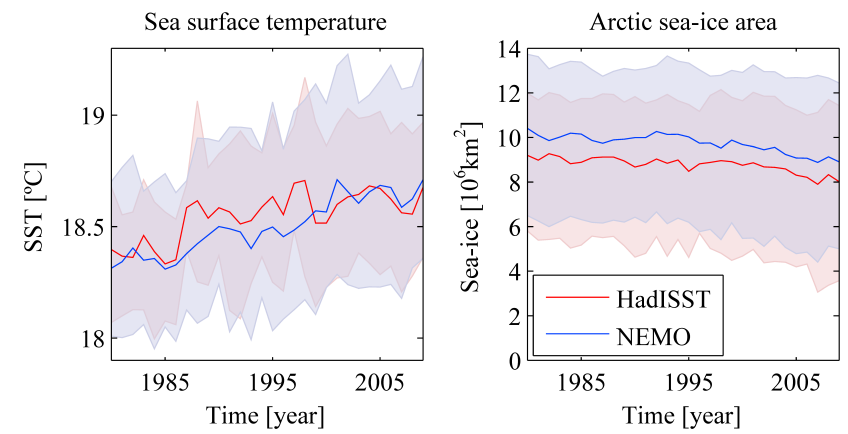

Fig. 3. The panels shows annual average (solid lines) and seasonal range (shaded regions) of sea surface temperature (left) and Arctic sea-ice area (right) for the HadISST climatology (red) and NEMO (blue).
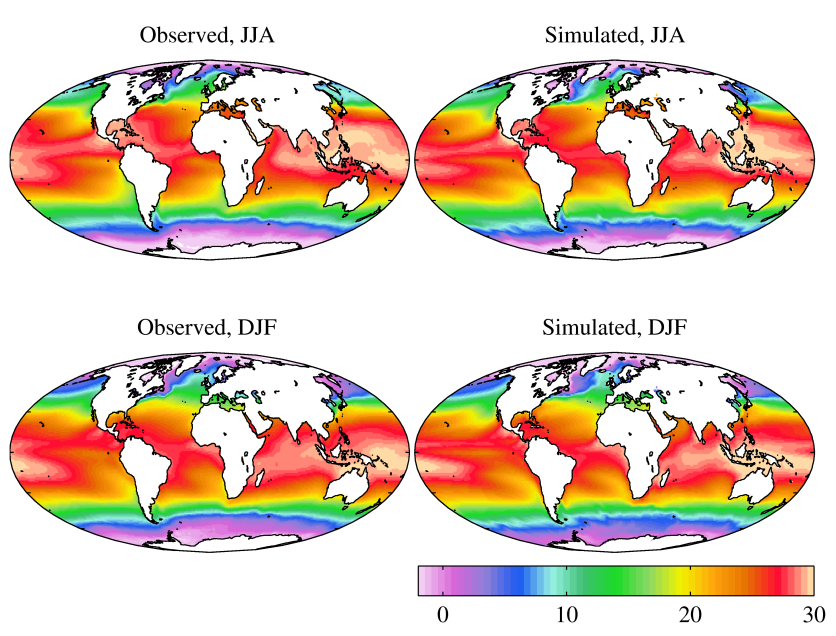

Fig. 4. Observed (left) and simulated (right) sea surface temperature for the periods June-July-August (JJA; top) and December-JanuaryFebruary (DJF; bottom). Averages based on the period 2000-2009 inclusive. Temperature in ${ }^{\circ} \mathrm{C}$.

SST is only one aspect of the physical ocean that influences ocean biology. Of greater importance is the vertical structure of the ocean since this governs the availability of light and nutrients for phytoplankton. Figure 5 illustrates this by comparing annual average fields of observational and NEMO mixed layer depth, pycnocline depth and nutricline depth. Observational fields are derived here from the WOA while, similarly to Fig. 4, model fields are averaged for the period 2000-2009. Mixed layer depth is calculated here using a temperature criterion of $0.5^{\circ} \mathrm{C}$ (Monterey and Levitus, 1997), and NEMO's global mean of $133 \mathrm{~m}$ is close to that calculated from the WOA, $127 \mathrm{~m}$. Nonetheless, there are a number of differences, with NEMO typically overestimating the size of areas of deep mixing at high latitudes, as well as areas of shallow mixed layer depth at tropical latitudes. Pycnocline depth is calculated using the method of Gnanadesikan et al. (2002), and geographical agreement between NEMO and that estimated from the WOA is generally better than
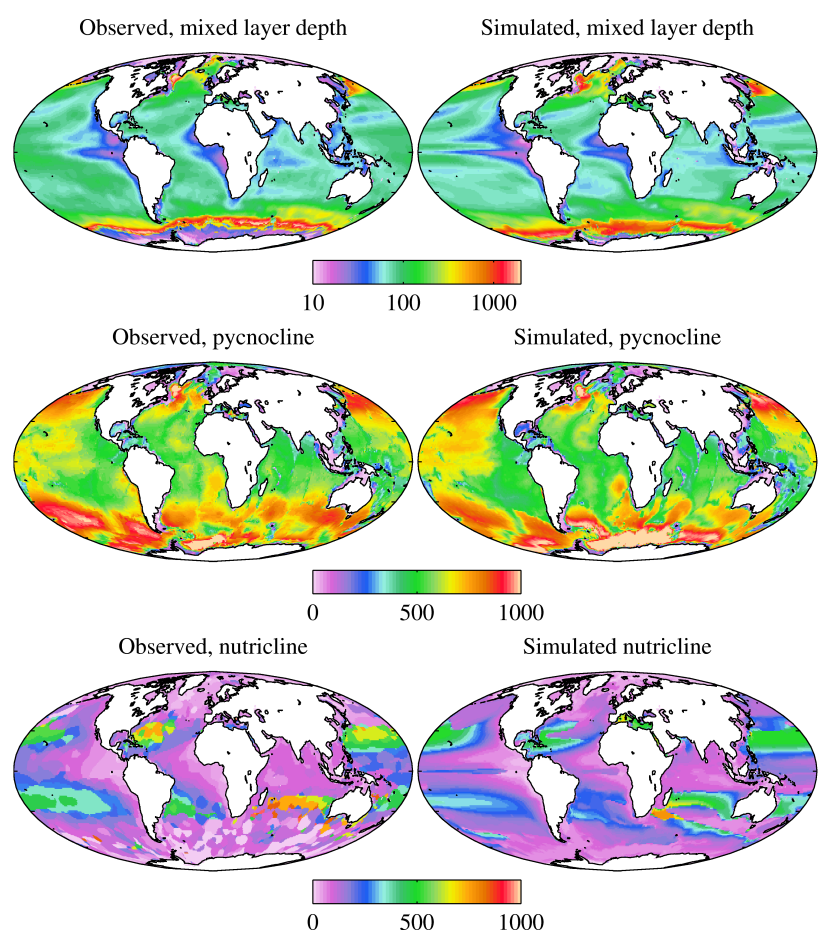

Fig. 5. Observed (left) and simulated (right) annual average mixed layer depth (top), pycnocline depth (middle) and nutricline depth (bottom). Averages based on the period 2000-2009 inclusive. All depths in metres, but note that mixed layer depth is shown on a logarithmic scale.

that of MLD. At the global scale, average pycnocline depth is $570 \mathrm{~m}$ in NEMO and $584 \mathrm{~m}$ in the WOA. Finally, while NEMO's nutricline (where the steepest vertical gradient in DIN concentration occurs) shows broad agreement with the WOA in terms of spatial patterns, there are significant differences, most notably within the subtropical gyres where NEMO's nutricline can be several hundred metres shallower than that estimated from the WOA. However, estimating nutricline depth from the WOA is complicated by its relatively low vertical resolution, and by limited data availability in some regions (note the blotches caused by interpolation in the Southern Ocean). NEMO's global average nutricline is $172 \mathrm{~m}$ compared to $174 \mathrm{~m}$ estimated from the WOA.

Figure 6 shows annual average sea-ice cover for the north and south polar regions. In the case of the Arctic, while NEMO tends to underestimate the level of ice cover in the high Arctic all year around, it does better with sea-ice extent, though slightly underestimating it (90.7\% of observed). The situation is less satisfactory in the Southern Hemisphere, where NEMO consistently and significantly underestimates sea ice $(49.0 \%$ of observed). While this is most noticeable in the summer, where sea-ice retreats almost completely ( $10.2 \%$ of observed), modelled winter sea ice is also substantially below that observed $(62.4 \%$ of observed; results not shown). 

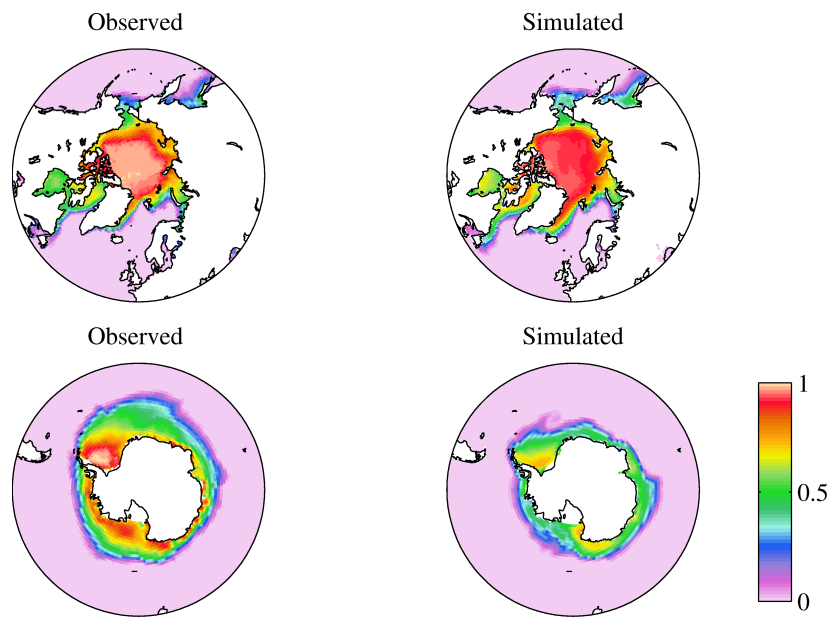

Fig. 6. Observed (left) and simulated (right) Arctic (top) and Antarctic (bottom) sea-ice cover averaged for the period 2000-2009 inclusive. Sea-ice cover is non-dimensional.

These Southern Ocean discrepancies in SST and sea ice are related to deficiencies in modelled large-scale circulation in this region. While the strength of the Antarctic Circumpolar Current (ACC) is estimated at around 130-140 Sv (Cunningham et al., 2003), in NEMO it is noticeably stronger at $220 \mathrm{~Sv}$, and toward the high end of comparable models (CMIP5 range of 90-264 Sv; Meijers et al., 2012). This is accompanied by stronger deep water formation around the margins of Antarctica, and the penetration of greater volumes of Antarctic Bottom Water (AABW) into the Pacific and, particularly, the Atlantic basins. As previous work with conventional surface forcing (e.g. Yool et al., 2011) has produced circulation states more in keeping with those observed, while experiments with initial physical states derived from the WOA instead of HadGEM2-ES are similar to that used here, the stronger circulation here would appear a function of the HadGEM2-ES forcing used in this work. Note that ocean circulation in other regions of the model is more congruent with that observed.

In terms of biogeochemistry, this excessive Southern Ocean circulation manifests itself in the distributions of biogeochemical tracers, most notably in over-ventilated deeper waters. For instance, this leads to elevated surface nutrient concentrations in this region and more distinct "tongues" of water with AABW nutrient signatures in the deep Atlantic and Pacific basins (results not shown; see Yool et al., 2013). In terms of dissolved oxygen, the elevated ventilation means that the higher concentrations of this tracer that occur in surface waters are mixed down to abyssal depths in NEMO, with values around $50 \mathrm{mmol}^{-3}$ higher than those observed. Away from the Southern Ocean, discrepancies are less pronounced and MEDUSA-2.0's nutrient and oxygen distributions are more similar to those observed. Recognised issues are iron stress in the equatorial Pacific tends to decrease production in this region; low silicic acid concentrations outside of the Southern Ocean, particularly in the northern Pacific where concentrations in this HNLC region should be higher; and too-shallow remineralisation, most noticeably in the equatorial Pacific, where subsurface concentrations of nutrients and DIC are elevated and oxygen depleted (Yool et al., 2013).

Switching to biogeochemical processes, the upper panels of Fig. 7 show observationally estimated and modelled fields of primary production. For simplicity of presentation, "Observed" here is a simple average of three estimates made using the VGPM (Behrenfeld and Falkowski, 1997), Eppley-VGPM (Carr et al., 2006) and CbPM (Westberry et al., 2008) techniques. In general, MEDUSA-2.0's spatiotemporal distribution of production follows that of observations, though there are a number of notable differences. For instance, North Atlantic productivity is too low, while Southern Ocean production is too high. In the tropics, equatorial upwelling regions are more productive in MEDUSA-2.0, while oligotrophic regions are less productive than in observational estimates; in addition, MEDUSA-2.0's total production, 41.6 $\mathrm{Pg} \mathrm{C} \mathrm{yr}^{-1}$, is slightly below the bottom of the broad range of observational estimates, $46-60 \mathrm{Pg} \mathrm{C} \mathrm{yr}^{-1}$ (though above many comparable models; e.g. Steinacher et al., 2010).

The lower panels of Fig. 7 compare patterns of observationally estimated (Takahashi et al., 2009) and modelled air-sea $\mathrm{CO}_{2}$ flux. Again, general patterns in MEDUSA-2.0 follow that of the observational climatology, though, again, there are a number of differences. For instance, outgassing in the Indian Ocean is much less pronounced in MEDUSA2.0, while outgassing in the Peruvian upwelling region is stronger. The modelled North Atlantic is also a more homogeneous sink than observations suggest (e.g. around Iceland), as well as being weaker in summer months (results not shown). Though, overall, model performance is reasonable, with modelled global annual net flux, $1.35 \mathrm{Pg} \mathrm{C} \mathrm{yr}^{-1}$, close to that estimated from observations, $1.42 \mathrm{Pg} \mathrm{Cyr}^{-1}$ (Takahashi et al., 2009).

As noted above, for a more comprehensive overview of simulated biogeochemistry, the reader is directed to Yool et al. (2013). In general, and in common with comparable models (Steinacher et al., 2010; Meijers et al., 2012), NEMO and MEDUSA-2.0 present a number of discrepancies with observed quantities. As such, qualitative and relative changes are of greater significance than their absolute magnitudes.

\subsection{0s versus 2090s}

In this subsection, the change in major biogeochemical processes across the 21 st century driven by climate and OA is examined and illustrated. For simplicity, analysis is primarily focused on two decades one century apart: the 1990s and the 2090s. The results presented are from the more extreme RCP 8.5 , with corresponding findings under RCP 2.6 presented in a following subsection. 

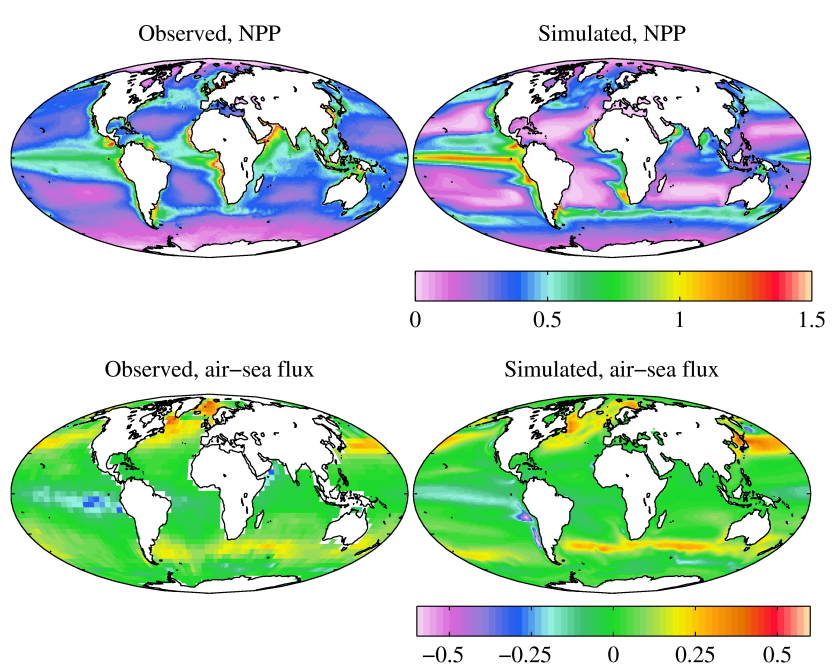

Fig. 7. Observational (left) and simulated (right) annual average primary production (top) and air-sea flux (bottom). Observational primary production here is in $\mathrm{g} \mathrm{C} \mathrm{m}^{-2} \mathrm{~d}^{-1}$ and is an average of the VGPM, Eppley-VGPM and CbPM estimates. Observational air-sea flux is in mol $\mathrm{C} \mathrm{m}^{-2}$ month $^{-1}$ and is taken from Takahashi et al. (2009).

Contrasting with Fig. 3, Fig. 8 shows the evolution of sea surface temperature and Arctic sea-ice area through the $21 \mathrm{st}$ century, for both RCP 2.6 and RCP 8.5. As previously noted, though $p \mathrm{CO}_{2}$ differs significantly between the two scenarios (particularly after 2030), sea surface temperature is changed to a more modest degree. In the case of RCP 2.6, SST is elevated by around $1^{\circ} \mathrm{C}$, whereas with RCP 8.5 it increases by around $3.5^{\circ} \mathrm{C}$. However, SST is approximately stable after 2050 in RCP 2.6 , but still increasing (at $0.5^{\circ} \mathrm{C}$ per decade) under RCP 8.5 at 2100.

While temperature trends are relatively smooth, Arctic sea ice shows distinctly more step-like behaviour under RCP 8.5. Around 2050, the seasonal minimum of Arctic sea-ice area drops dramatically by more than $2 \times 10^{6} \mathrm{~km}^{2}$ over the course of just a decade, and from around 2070 onwards, the Arctic experiences near-zero sea ice for at least some of the year. By contrast, RCP 2.6 shows Arctic sea-ice stabilisation after around 2050, with an average cover approximately $70 \%$ that in the 1980s. Note, however, that even under RCP 2.6's weaker warming, the modelled seasonal minimum is less than half of that during the 1980s.

To illustrate the geographical patterns in the physical ocean under climate change, Fig. 9 shows decadal-average SST and mixed layer depth (MLD) for the 1990s and 2090s under RCP 8.5. Though there are regions such as the Southern Ocean where warming is less pronounced, most other areas are significantly warmer by the 2090s. Equatorial waters, for instance, are around $4-5{ }^{\circ} \mathrm{C}$ warmer, while high latitude regions in the Northern Hemisphere are $5-10^{\circ} \mathrm{C}$ warmer. Mixed layer depths are generally shallower, with significant declines in mixing in regions, such as the subpolar North
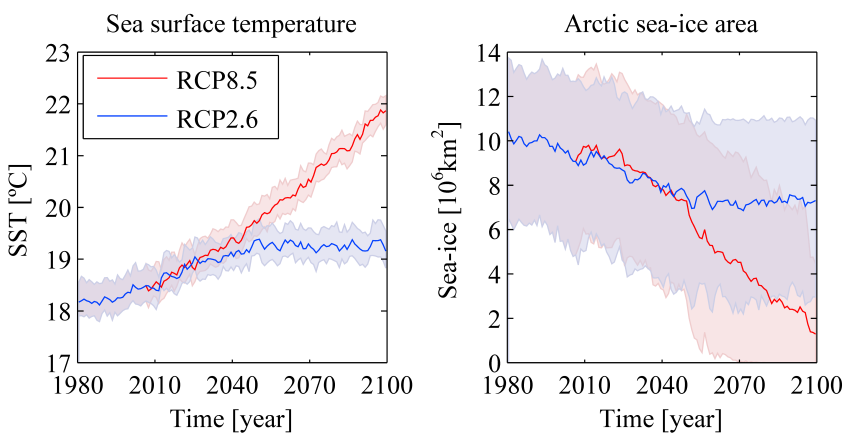

Fig. 8. The panels shows annual average (solid lines) and seasonal range (shaded regions) of sea surface temperature (left) and Arctic sea-ice area (right) for RCP 2.6 (blue) and RCP 8.5 (red).
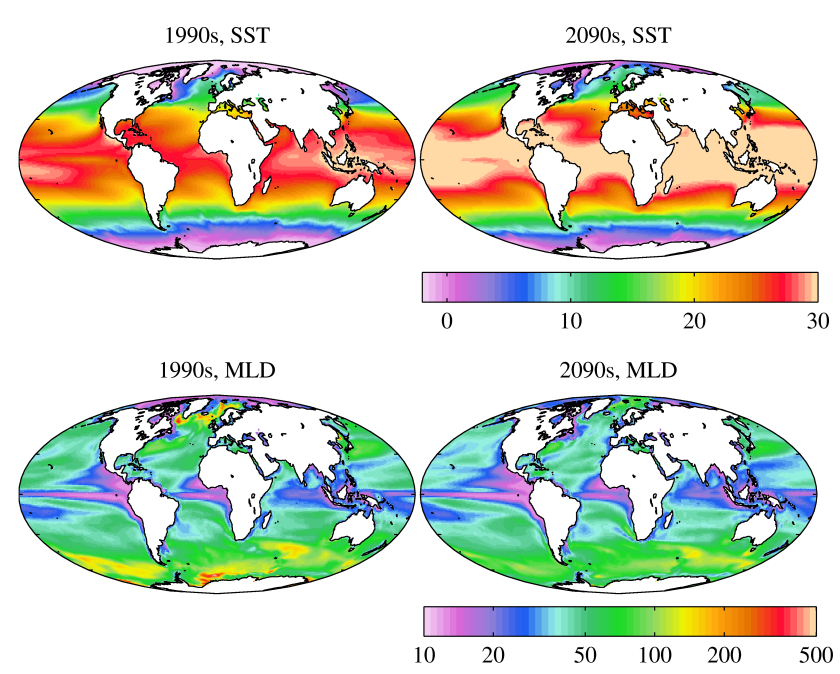

Fig. 9. Annual average 1990s (left) and 2090s (right) sea surface temperature (top) and mixed layer depth (bottom). Temperature in ${ }^{\circ} \mathrm{C}$, mixed layer depth in $\mathrm{m}$ (note logarithmic scale).

Atlantic and the Southern Ocean, where deep water formation typically occurs. Already shallow mixing in the tropics and subtropics is further shoaled. An exception is the Arctic Ocean, where waters previously isolated by permanent seaice cover are now (at least) seasonally ice-free, and mixing is enhanced (MLDs are broadly doubled, $15 \mathrm{~m}$ to $30 \mathrm{~m}$ ).

Figure 10 further illustrates the changes in MLD, together with those in pycnocline and nutricline depths. At global scale, MLD decreases from a 1990 s average of $135 \mathrm{~m}$ to a 2090s average of $113 \mathrm{~m}$, and while there is considerable scatter in local changes, it is clear that there is a systematic and significant shallowing of MLD in those regions which previously had deep mixed layers. Pycnocline depths also decrease from a 1990s average of $574 \mathrm{~m}$ to a 2090s average of $520 \mathrm{~m}$. Figure 10 shows that while changes are not as large as for MLD, there is a tendency for regions with deeper pycnoclines $(>500 \mathrm{~m})$ to experience the largest absolute shallowing. In particular, the deep pycnoclines in the northern 


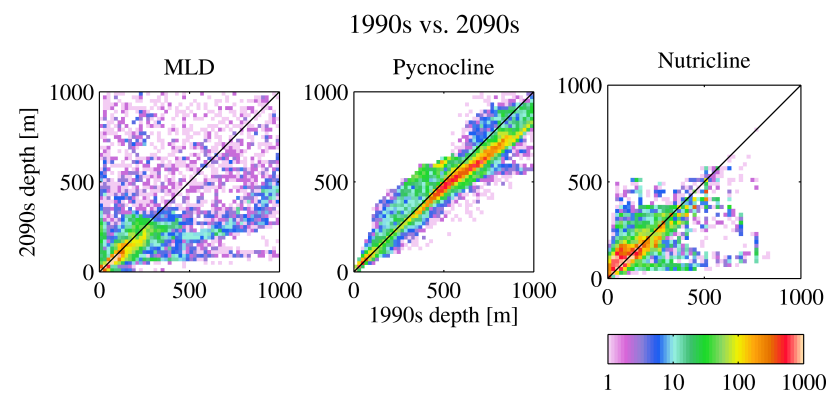

Fig. 10. Intercomparison of annual average 1990s ( $x$ axis) and 2090s ( $y$ axis) mixed layer depth (left), pycnocline depth (middle) and nutricline depth (right). Color represents the density of model grid cells, on a logarithmic scale. The black diagonal line in each panel denotes the $1: 1$ relationship between plotted fields.

portions of the Atlantic and Pacific basins show pronounced shallowing. Changes in nutricline depth are different again, though the 1990s average of $174 \mathrm{~m}$ also declines, to $165 \mathrm{~m}$, by the 2090s. However, as Fig. 10 shows, shallow nutriclines $(<200 \mathrm{~m})$ tend to deepen from the 1990s to the 2090s, while deep nutriclines $(>300 \mathrm{~m})$ instead broadly tend to shoal, though there is a degree of scatter about this general pattern. This deepening occurs because, in temperate and sub-polar regions where there were once shallower nutriclines, warming enhances stratification, with the result that mixing is unable to replenish nutrient levels from deeper waters.

As an illustration of the contrasting nature of the poles, Fig. 11 shows the seasonal maxima of sea-ice cover for both the north and south poles for the 1990s and 2090s. Though Southern Ocean sea-ice cover has significantly declined by $-38.2 \%$ (March: $-95.5 \%$; September: $-33.9 \%$ ), Arctic sea ice is catastrophically depleted by $-78.8 \%$ (March: $-55.4 \%$; September: $-100 \%$ ), with sea ice confined to areas adjacent to surrounding landmasses, and with almost no sea ice over the north pole itself. During summer months (results not shown), both Antarctic and Arctic sea ice is entirely lost throughout their respective regions.

Figures 12-15 illustrate the change in key biogeochemical variables and processes between the 1990s and the 2090s. In Fig. 12, the impact on the surface concentrations of macronutrients is shown. DIN concentrations are uniformly decreased, particularly in the equatorial Pacific and, especially, the North Atlantic. The North Pacific is less impacted, with almost no change in the west of the basin, and modest changes in the east. Silicic acid concentrations are similarly impacted, though already low concentrations in the North Atlantic make the changes there less pronounced. The Southern Ocean sees the largest regional declines, particularly adjacent to the Antarctic landmass (though concentrations remain far above limiting values), but there is also a region of increase in a northward plume in deep water off the western coast of South America. Overall, 2090s surface DIN changes by $-11.2 \%$, whereas surface silicic acid changes by only
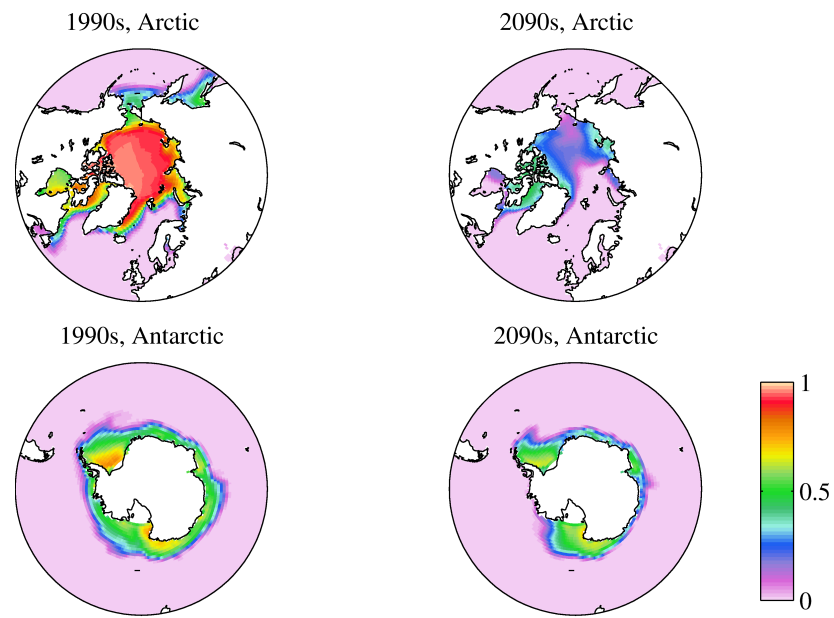

Fig. 11. Seasonal maximum 1990s (left) and 2090s (right) sea-ice cover for the Arctic (top; March) and Antarctic (bottom; September). Sea-ice cover is non-dimensional.
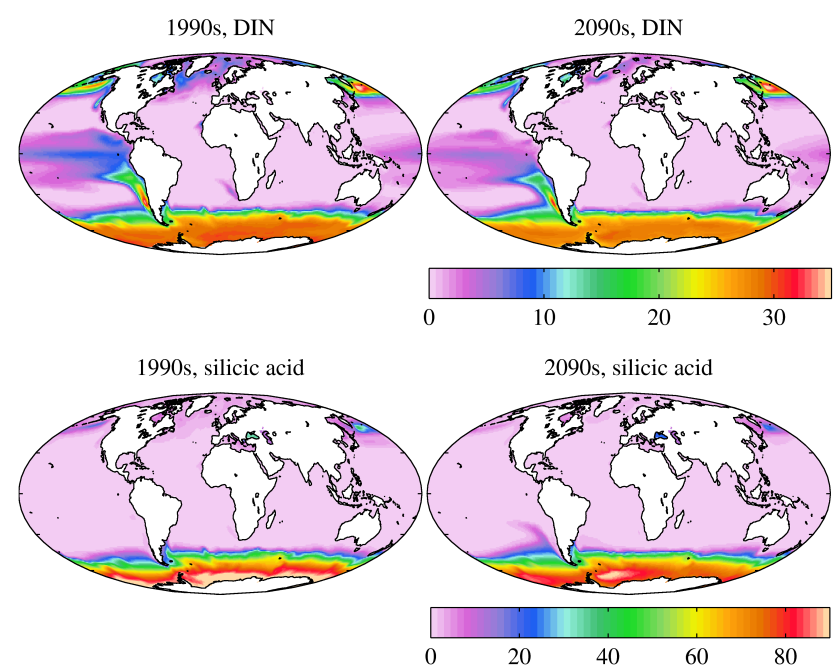

Fig. 12. Annual average 1990s (left) and 2090s (right) surface DIN (top; $\mathrm{mmol} \mathrm{N} \mathrm{m}^{-3}$ ) and surface silicic acid (bottom; $\mathrm{mmol} \mathrm{Si} \mathrm{m}^{-3}$ ).

$-1.7 \%$ (upper $100 \mathrm{~m}$ changes are, respectively, $-8.7 \%$ and $-1.5 \%)$.

The situation is somewhat different for the micronutrient iron (MEDUSA-2.0 uses the submodel of Dutkiewicz et al., 2005; see Yool et al., 2013 for more details). As well as being transported to the surface ocean by physical processes, this nutrient is directly supplied to the ocean in MEDUSA2.0 by aeolian deposition (global; spatio-temporally variable) and by benthic supply (coastal; spatio-temporally constant). As such, its patterns are distinct and different from those of macronutrients, and these differences continue into its future response to climate change (results not shown). In marked contrast to both nitrogen and silicon, Atlantic Ocean iron concentrations - particularly those at high northern latitudes - increase. The Pacific and Southern oceans generally 
see declines in surface iron, with the North Pacific showing large-scale drops (though with some coastal increases on its western margin). The plume of silicic acid in the southeastern Pacific noted previously is associated with one such decline in iron. Note, of course, that there is no modelled change in aeolian iron into the future - total deposition and its geographical pattern remain fixed despite climate change.

In contrast to nutrient concentrations, dissolved oxygen concentrations, surface and deep, serve to illustrate a quite different impact of climate warming, namely on the solubility of biogeochemically significant gases. Isoclines of oxygen are uniformly pushed polewards in both hemispheres, with particularly large declines in the Arctic Ocean, where both elevated temperatures and increased exposure to the atmosphere occur under future climate change (results not shown). Globally averaged, the surface dissolved oxygen concentration changes by $-5.9 \%$ between the 1990 s and the 2090s. Meanwhile, total oceanic concentration of dissolved oxygen falls by $-2.1 \%$, and there is an increase in the volume of suboxic $\left(<20 \mathrm{mmol} \mathrm{O}_{2} \mathrm{~m}^{-3}\right)$ waters by $12.5 \%$. Since the simulation forecasts lower export production into the future, subsurface oxygen demand by remineralisation is also reduced, which should instead favour higher concentrations. However, the decline in dissolved oxygen is driven in part by stronger stratification and weaker mixing that act to decrease ventilation of the ocean interior, and in part by warmer SSTs that decrease the saturation concentrations of oxygen in newly formed water masses. In passing, note that MEDUSA-2.0 overestimates the present-day (2000-2009) volume of suboxic water relative to the WOA $\left(30.4 \times 10^{6} \mathrm{~km}^{3}\right.$ compared to $13.1 \times 10^{6} \mathrm{~km}^{3}$ ).

In terms of the ocean biota, Fig. 13 shows the changes in both surface chlorophyll concentrations and total phytoplankton biomass across the 21st century. The largest changes in terms of chlorophyll occur in the Northern Hemisphere, with the North Atlantic showing significant and widespread declines, particularly in the east, while the North Pacific shows a marked increase, particularly in the west. Changes elsewhere are much less dramatic, typically being small declines. In terms of phytoplankton standing stock, these patterns are generally repeated, although the Pacific increase in chlorophyll is on top of a marked decline in underlying biomass. Overall, annual average biomass changes by $-5.7 \%$ over the 21 st century, with the decline split unevenly between the diatoms $(-12.2 \%)$ and the non-diatoms $(-3.5 \%)$. However, the biomass of both groups increases significantly in one region, the Arctic $(+25.8 \%,+58.5 \%$ respectively), albeit from a low base in the ice-bound 1990s.

Switching from standing stock to productivity, Fig. 14 shows total primary production, and the fraction that occurs in the upper mixed layer, between the 1990s and the 2090s. Globally integrated production changes by $-6.3 \%$, but there is considerable regional variability. The Atlantic sees the largest decline, falling by $-21.1 \%$, while the Arctic sees the greatest rise, $+59.1 \%$ (again, from a relatively low base).
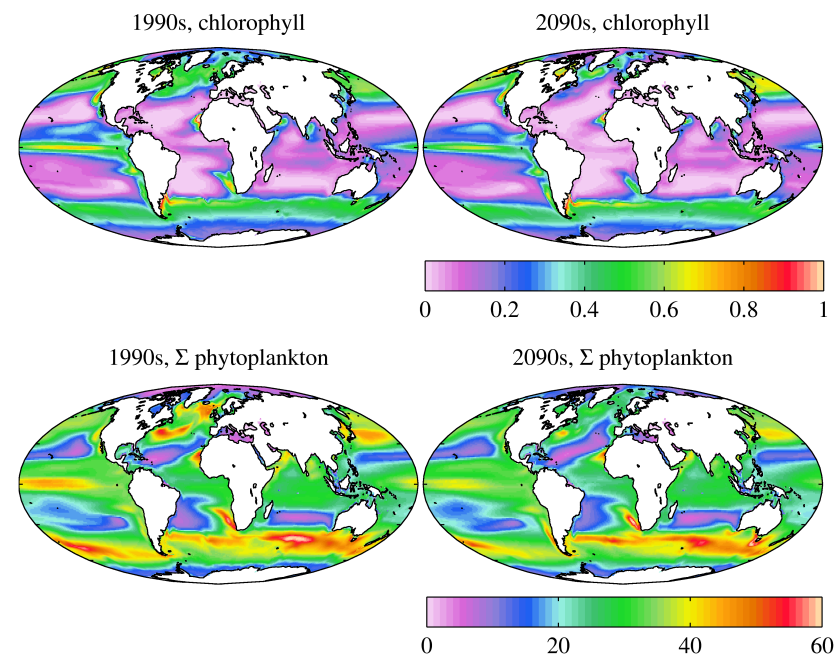

Fig. 13. Annual average 1990s (left) and 2090s (right) surface chlorophyll (top; $\mathrm{mg} \mathrm{chl} \mathrm{m}^{-3}$ ) and vertically integrated phytoplankton biomass (bottom; $\mathrm{mmol} \mathrm{N} \mathrm{m}^{-2}$ ).

Interestingly, though phytoplankton biomass declines in the North Pacific, productivity follows surface chlorophyll and shows a noticeable increase. In terms of where productivity lies vertically, the lower panels of Fig. 14 show that, almost universally, less production occurs within the mixed layer by the 2090s. This is most marked in the Atlantic $(-27.5 \%)$ and the Arctic $(-31.7 \%)$ oceans.

These changes to phytoplankton productivity are driven by the increasing ocean stratification - and the resulting nutrient changes - previously shown. Figure 15 illustrates another facet of this, namely the most limiting nutrient for both modelled phytoplankton. In the case of non-diatoms, the area of the ocean most limited by the availability of iron decreases as DIN becomes more limiting, most notably in the North Atlantic and parts of the Arctic. For diatoms, the Atlantic regions where productivity is most affected by DIN grow, but otherwise silicic acid limitation imposes restrictions on growth. Iron does play a more important role in the southern Pacific (particularly in the east), but in the Northern Hemisphere, iron stress becomes relatively less significant.

Though phytoplankton productivity has declined, aspects of the changes in ocean physics should favour their growth. For instance, warmer temperatures permit higher maximum growth rates (Eppley, 1972), while shallower mixing confines phytoplankton cells within a thinner mixed layer and increases the average irradiance that they experience. Table 1 presents a summary of the changes in phytoplankton biomass, productivity and growth rates between the 1990s and 2090s. As already noted, both biomass and productivity decline across the 21 st century, but this occurs against the backdrop of increasing potential growth rates, both for nondiatoms and diatoms. However, both modelled phytoplankton groups experience increasing nutrient limitation, and 

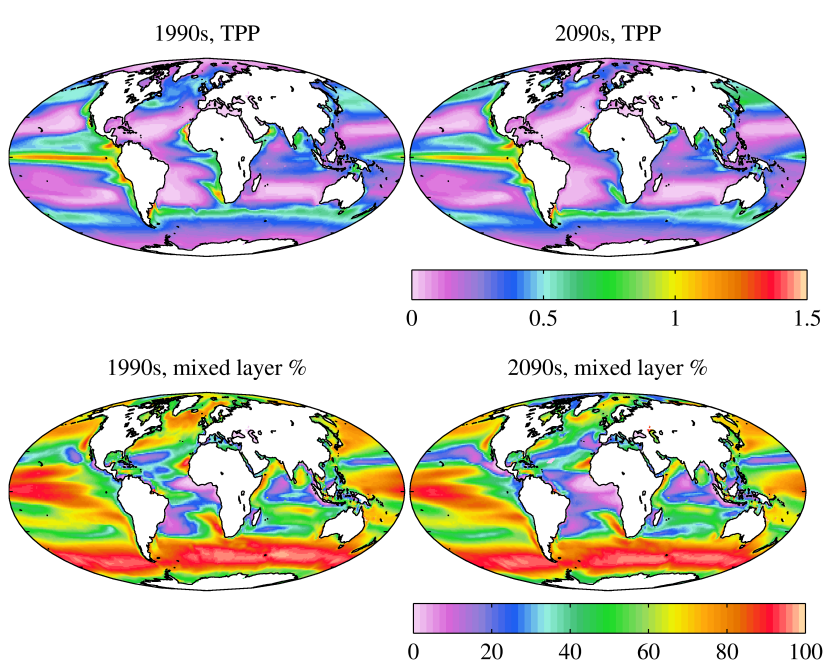

Fig. 14. Annual average 1990s (left) and 2090s (right) primary production (top; $\mathrm{g} \mathrm{C} \mathrm{m}^{-2} \mathrm{~d}^{-1}$ ) and mixed layer fraction (bottom; \%).
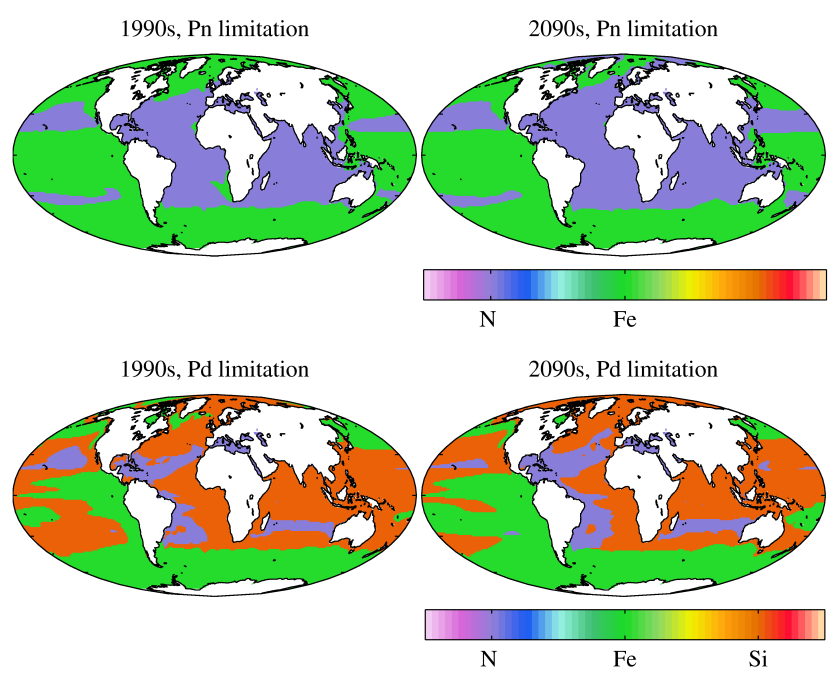

Fig. 15. Annual average 1990s (left) and 2090s (right) limiting nutrient for non-diatom phytoplankton (top; -) and limiting nutrient for diatom phytoplankton (bottom; -).

actual growth rates are markedly lower than potential ones. Nonetheless, in the case of non-diatoms, the increase in potential growth rates is sufficient to - on average - marginally offset increasing nutrient limitation, although this is not the case for model diatoms. Note that the average growth rates shown here are calculated using a weighting by biomass to avoid being skewed by those from warm, well-lit, but unproductive, regions such as ocean gyres.

The patterns in primary production mentioned above are broadly echoed in those of detritus production and export production at $100 \mathrm{~m}$ (results not shown). The former declines globally by $-7.6 \%$ (Atlantic: $-24.2 \%$; Arctic: $+63.7 \%$ ), and the latter by $-11.8 \%$ (Atlantic: $-28.3 \%$; Arctic: $+48.8 \%$ ). Interestingly, the magnitude of change be-
Table 1. Changes in key phytoplankton growth indicators between the 1990s and 2090s. Biomass and primary production refer to the average standing stock of phytoplankton and the production of new biomass. $V_{\mathrm{P}, \max }$ refers to the potential maximum growth rate of phytoplankton based on temperature- and light-limitation. Nutrient limitation refers to the restriction placed on this by nutrient

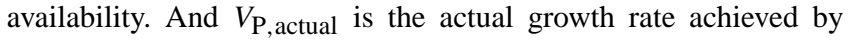
phytoplankton. Growth rates and nutrient limitation are biomassweighted averages to discount the influence of large, unproductive ocean regions such as the oligotrophic gyres that have high potential growth rates, but extreme nutrient limitation and low biomass.

\begin{tabular}{llllll}
\hline \multicolumn{2}{c}{ Field } & \multicolumn{2}{c}{ Non-diatom } & \multicolumn{2}{c}{ Diatom } \\
& & $1990 \mathrm{~s}$ & $2090 \mathrm{~s}$ & $1990 \mathrm{~s}$ & $2090 \mathrm{~s}$ \\
\hline $\begin{array}{l}\text { Biomass } \\
\text { Primary } \\
\text { production }\end{array}$ & Pg C & 0.5991 & 0.5779 & 0.2053 & 0.1804 \\
$V_{\mathrm{P}, \max }$ & $\mathrm{d}^{-1}$ & 35.13 & 33.57 & 6.70 & 5.71 \\
$\begin{array}{l}\text { Nutrient } \\
\text { limitation }\end{array}$ & - & 0.5977 & 0.6379 & 0.3900 & 0.4068 \\
$V_{\mathrm{P}, \text { actual }}$ & $\mathrm{d}^{-1}$ & 0.3698 & 0.3468 & 0.2896 & 0.2712 \\
\hline
\end{tabular}

tween the 1990s and 2090s increases as detrital material sinks down the water column. At $200 \mathrm{~m}$ it is $-16.0 \%$; at $500 \mathrm{~m}$ it is $-25.8 \%$; and at $1000 \mathrm{~m}$ it is $-40.7 \%$. This is indicative of shallower remineralisation, driven in part by warmer ocean temperatures and faster recycling, and in part by changes to detrital ballasting (see below).

Alongside organic material, MEDUSA-2.0 estimates the production of the biominerals opal (produced by diatoms) and $\mathrm{CaCO}_{3}$ (a function of fast-sinking particle production). As noted above, the latter is impacted by ocean acidification as well as changes in ocean productivity. As shown in the upper panels of Fig. 16, opal production broadly declines into the future, falling by $-5.8 \%$, but with a strong decline in the Atlantic Ocean $(-18.0 \%)$ and a small increase in the Southern Ocean $(+2.9 \%)$. This general decline is smaller than the drop in both diatom biomass $(-12.2 \%)$ and diatom fraction of primary production $(-14.1 \%)$, and indicates an increase in the $\mathrm{Si}: \mathrm{N}$ ratio of diatom productivity (which is also apparent in the $\mathrm{Si}: \mathrm{N}$ ratio of diatom standing stock). This is driven by MEDUSA-2.0's diatom silicon submodel (Mongin et al., 2006), which permits diatoms to continue to uptake silicic acid and synthesise opal even while biomass production is limited by nitrogen or iron availability.

The production of $\mathrm{CaCO}_{3}$ changes much more significantly during the 21st century. As the lower panels of Fig. 16 show, production universally declines, with a global average fall of $-54.9 \%$ between the 1990s and 2090s. Unsurprisingly, given changes in general productivity, this decline is largest in the Atlantic Ocean ( $-66.8 \%)$, but it occurs even in the Arctic Ocean $(-47.3 \%)$ which is otherwise considerably more productive $(+59.1 \%)$. This latter feature is due to the acidification feedback included in MEDUSA-2.0 mentioned previously, which has its strongest impact in Arctic waters 

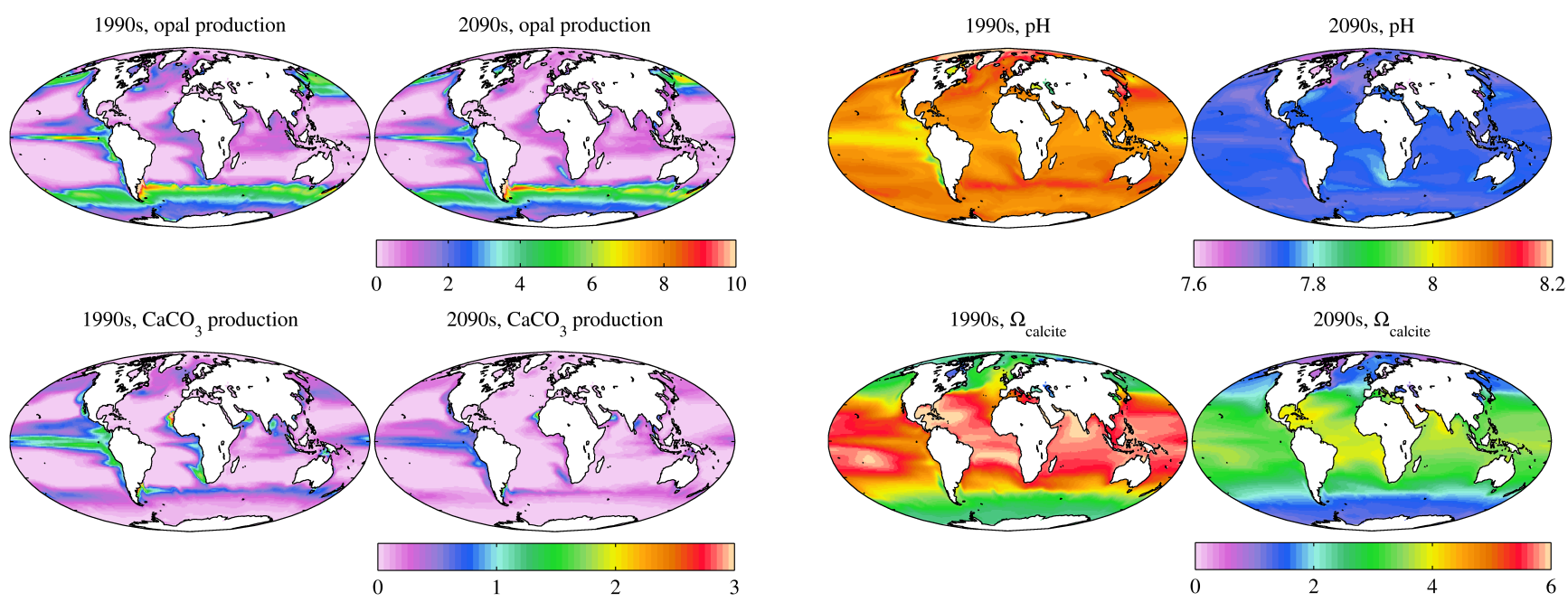

Fig. 16. Annual average 1990s (left) and 2090s (right) opal production (top; mmol Si m${ }^{-2} \mathrm{~d}^{-1}$ ) and $\mathrm{CaCO}_{3}$ production (bottom; $\left.\mathrm{mmol} \mathrm{C \textrm {m } ^ { - 2 }} \mathrm{d}^{-1}\right)$.

where the solubility of $\mathrm{CaCO}_{3}\left(\Omega_{\text {calcite }}\right)$ is most significantly impacted.

Figure 17 shows the impact of ocean acidification on both surface $\mathrm{pH}$ and $\Omega_{\text {calcite. During the } 21 \text { st century, the global }}$ $\mathrm{pH}$ declines from 8.07 to 7.74 , which corresponds to an increase in proton concentration $\left(\left[\mathrm{H}^{+}\right]\right)$by a factor of 2.18 . The change in $\mathrm{pH}$ is greatest in the Arctic Ocean, where $\left[\mathrm{H}^{+}\right]$increases by a factor of 2.81 ( $\mathrm{pH}$ falls from 8.15 to 7.69 ). Globally, $\Omega_{\text {calcite }}$ falls from 4.56 to 2.72 , but in the Arctic Ocean it changes from 2.37 to 1.08 . While this spatio-temporal average value is above 1.0 , the Arctic is widely unsaturated with respect to $\mathrm{CaCO}_{3}$ both regionally and seasonally by the 2090s.

Figure 18 shows the corresponding changes in profiles of carbonate-relevant properties over the 21 st century. While the upper right panel shows the nearly unchanging profile of ocean alkalinity, the upper left panel shows the steady invasion of the ocean by anthropogenic $\mathrm{CO}_{2}$. The result of which can be seen in the lower two panels showing $\mathrm{pH}$ and $\Omega_{\text {calcite }}$. These show the significant reorganisation of the ocean's carbonate chemistry system in the surface and midwater driven by ocean acidification.

Finally, to illustrate the temporal progression of ocean acidification, Fig. 19 shows the calendar time at which surface waters in the Arctic and Antarctic - the regions most impacted by acidification during the 21 st century - first become undersaturated (based on monthly average output). The upper panel shows the results for the calcite polymorph of $\mathrm{CaCO}_{3}$, while the lower panels show the same for the aragonite polymorph. Because calcite is the more stable polymorph, it was chosen as the yardstick with MEDUSA-2.0 estimates changes in pelagic calcification in the ocean. However, as the panels show, this choice gives a more conser-
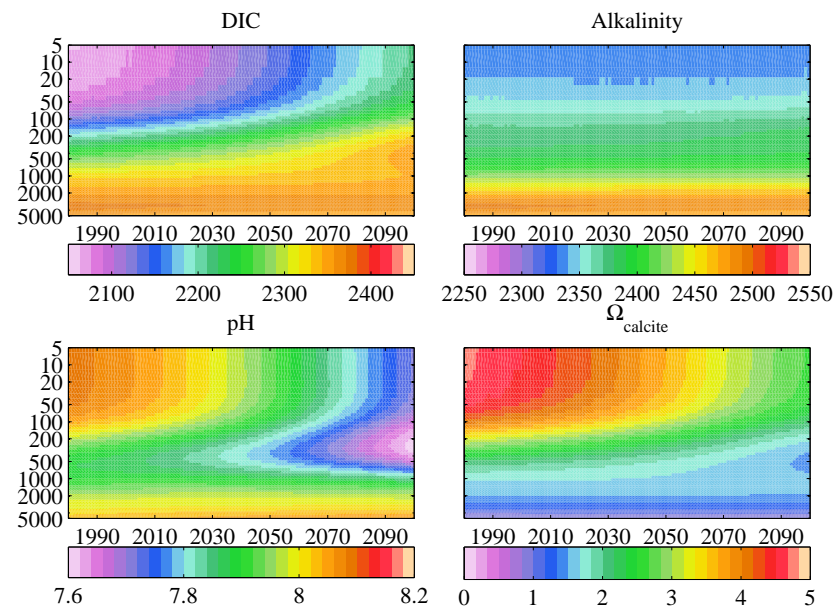

Fig. 18. Time evolution of global vertical profiles of DIC (top left; mmol $\mathrm{C} \mathrm{m}^{-3}$ ), alkalinity (top right; meq $\mathrm{m}^{-3}$ ), $\mathrm{pH}$ (bottom left; -) and $\Omega_{\text {calcite }}$ (bottom right; -).

vative answer on impacts and may miss significantly earlier change to polar communities caused by shifts in the ecological success of calcifying organisms. Nonetheless, even in the case of calcite parts of the Arctic Ocean are estimated by MEDUSA-2.0 to be undersaturated by the middle of the 21 st century. The Southern Ocean does not become undersaturated during this century, but the aragonite panel indicates ubiquitous undersaturation by the closing decades of the century. Note also that while the Southern Ocean exhibits a "bullseye" appearance whereby time-of-first-undersaturation correlates well with latitude, the Arctic Ocean shows considerable horizontal heterogeneity associated with bathymetry, sea-ice formation, runoff receipt and the sources of its water masses (Atlantic vs. Pacific). This complexity of response 

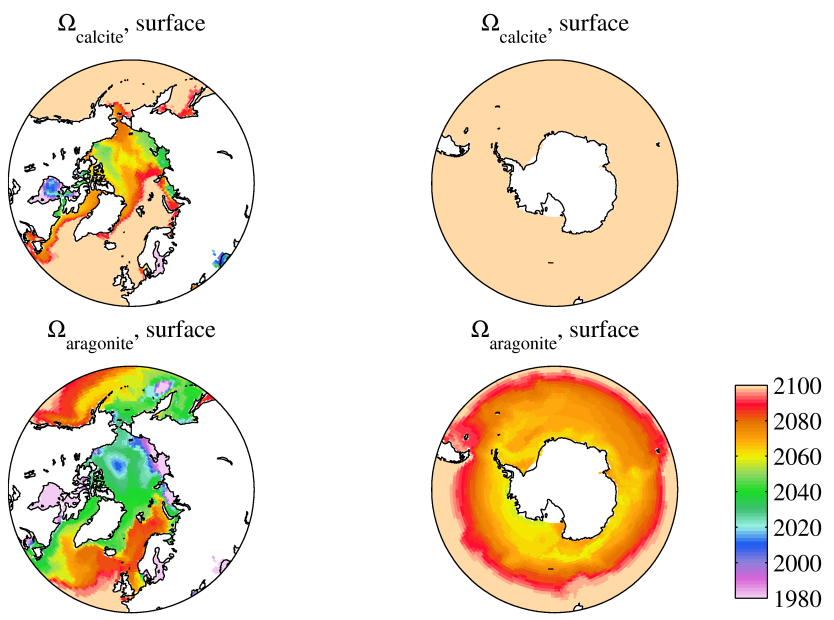

Fig. 19. Calendar time at which monthly average $\Omega_{\text {calcite }}$ (top) and $\Omega_{\text {aragonite }}$ (bottom) is first below 1.0 (i.e. $\mathrm{CaCO}_{3}$ is undersaturated). The panels focus on the north and south polar regions since these experience the greatest changes.

will likely complicate monitoring efforts in this latter basin (Popova et al., 2013).

\subsection{RCP 2.6 versus RCP 8.5}

In the preceding section, emphasis was placed on the more extreme of the two scenarios considered in this work, RCP 8.5. Here, the results from RCP 2.6 are examined.

As already shown in Figs. 2 and 8, RCP 2.6 displays significant climate warming in spite of considerably lower $\mathrm{CO}_{2}$ concentrations relative to RCP 8.5. However, as illustrated by Fig. 20 and Tables 2 and 3, the biogeochemical changes are markedly weaker than those found under RCP 8.5. Consistent with the stabilisation of climate change during the latter half of the 21st century, and with the decline in atmospheric $p \mathrm{CO}_{2}$, downward trends from the first half of the century cease or are in reverse by 2100 .

Nonetheless, the impacts of ocean acidification are still felt under RCP 2.6, with the largest percentage change in Table 3 being that of $\mathrm{CaCO}_{3}$ production. The decline in calcification and the acidification-driven shoaling of the lysocline can also be seen in the downward fluxes of export production. While, as noted above, primary (and detrital) production is elevated in the $2090 \mathrm{~s}(+1.4 \% ;+1.1 \%), \mathrm{CaCO}_{3}$ production still significantly declines $(-9.6 \%)$, and export production at $100 \mathrm{~m}$ and, especially, $1000 \mathrm{~m}$ is significantly decreased $(-8.2 \%)$.

Overall, while the climate-driven impacts on ocean biogeochemistry can be much lower under RCP 2.6, those from ocean acidification are still very evident.

\subsection{Calcification feedback}

In the results of RCP 8.5 above, attention was drawn to OA impacts on calcification in MEDUSA-2.0. However, as dis-
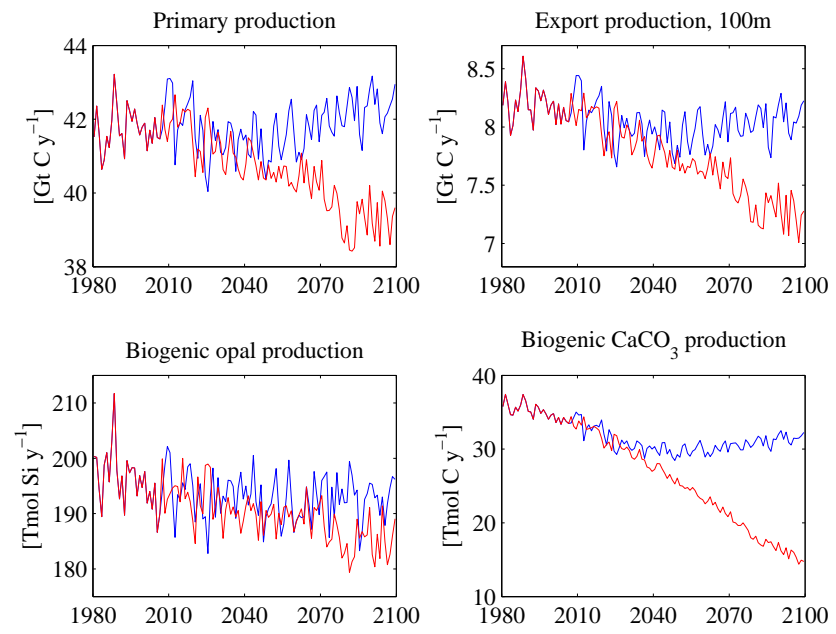

Fig. 20. Time evolution of integrated primary production (top left), export production at $100 \mathrm{~m}$ (top right), biogenic opal production (bottom left) and biogenic $\mathrm{CaCO}_{3}$ production (bottom right) for RCP 2.6 (blue) and RCP 8.5 (red).

Table 2. Upper $100 \mathrm{~m}$ tracer concentrations, RCP 2.6 versus RCP 8.5 .

\begin{tabular}{llll}
\hline Field & $\begin{array}{l}\text { 1990s average } \\
\mathrm{mmol} \mathrm{m}^{-3}\end{array}$ & $\begin{array}{l}\Delta \text { 2090s, } \\
\text { RCP 8.5 \% }\end{array}$ & $\begin{array}{l}\Delta \text { 2090s, } \\
\text { RCP 2.6\% }\end{array}$ \\
\hline Non-diatoms & 0.1796 & -1.74 & +1.10 \\
Diatoms & 0.0639 & -10.65 & -2.11 \\
Microzooplankton & 0.1017 & -4.03 & +1.31 \\
Mesozooplankton & 0.1152 & -9.11 & +0.77 \\
DIN & 8.669 & -8.40 & +3.04 \\
Silicic acid & 12.52 & -1.54 & +0.15 \\
Iron & 0.0006 & +1.23 & -1.17 \\
DIC & 2098 & +6.41 & +1.32 \\
Alkalinity & 2350 & +0.13 & +0.02 \\
Oxygen & 242.9 & -5.35 & -1.77 \\
\hline
\end{tabular}

cussed in the introduction, there remains considerable uncertainty in how this process will respond to OA into the future, and how best to model it. Here, the results of a sensitivity experiment, $\mathrm{RCP} 8.5 \mathrm{~B}$, in which calcification is made insensitive to $\mathrm{OA}$ are examined.

Insensitivity to 21 st century OA was implemented as follows. Equation (1) was used as normal until the end of year 1999 . At this point, $f o\left(\Omega_{\text {calcite }}\right)$ was switched from dynamic variable to one based on an unchanging seasonal climatology. This climatology was prepared from monthly averages of $f o\left(\Omega_{\text {calcite }}\right)$ for the 1990 s. Note that though this effectively decoupled the synthesis of $\mathrm{CaCO}_{3}$ from OA, the dissolution of $\mathrm{CaCO}_{3}$ was still modelled as a function of ambient $\Omega_{\text {calcite. }}$.

Tables 4 and 5 respectively present a summary of the changes in upper ocean tracer concentrations, and major biogeochemical fluxes that result. In terms of tracer changes, 
Table 3. Major biogeochemical fluxes, RCP 2.6 versus RCP 8.5 . Note that the $\Delta 2090$ s values shown for surface $\mathrm{pH}$ and $\Omega_{\text {calcite }}$ are instead 2090s values.

\begin{tabular}{|c|c|c|c|c|}
\hline Flux & Units & $\begin{array}{l}1990 \mathrm{~s} \\
\text { average }\end{array}$ & $\begin{array}{l}\Delta 2090 \mathrm{~s}, \\
\mathrm{RCP} 8.5 \%\end{array}$ & $\begin{array}{l}\Delta 2090 \mathrm{~s}, \\
\text { RCP } 2.6 \%\end{array}$ \\
\hline Primary production & $\mathrm{PgCyr}^{-1}$ & 41.83 & -6.07 & +1.37 \\
\hline Diatom fraction & $\%$ & 16.02 & -14.72 & -3.02 \\
\hline Opal production & Tmol Si yr $^{-1}$ & 195.8 & -5.71 & -1.33 \\
\hline $\mathrm{CaCO}_{3}$ production & $\mathrm{Tmol} \mathrm{C} \mathrm{yr}^{-1}$ & 34.96 & -55.57 & -9.59 \\
\hline Detritus production & $\mathrm{PgC} \mathrm{yr}^{-1}$ & 28.65 & -7.63 & +1.09 \\
\hline Export, $100 \mathrm{~m}$ & $\mathrm{PgC}_{\mathrm{yr}}{ }^{-1}$ & 8.200 & -11.74 & -1.26 \\
\hline Export, $1000 \mathrm{~m}$ & $\mathrm{PgC}_{\mathrm{yr}}{ }^{-1}$ & 0.3656 & -40.72 & -8.15 \\
\hline Export, seafloor & $\mathrm{PgC}_{\mathrm{yr}}{ }^{-1}$ & 0.6604 & -6.47 & +8.85 \\
\hline Benthic $\mathrm{C}_{\text {org }}$ & $\mathrm{PgC}$ & 0.0608 & -3.88 & +8.46 \\
\hline Surface $\mathrm{pH}$ & - & 8.073 & 7.735 & 8.007 \\
\hline Surface $\Omega_{\text {calcite }}$ & - & 4.555 & 2.717 & 4.184 \\
\hline
\end{tabular}

while the two simulations are not identical, most differences are relatively minor. However, there are differences in the sign of change between the 1990s and 2090s for silicic acid, iron and alkalinity. Previously a small increase in surface iron was reported, but here it is a larger decrease, while silicic acid shows the reverse. These differences show no systematic geographical patterns, nor are they reflective of largescale changes in biogeochemical fluxes (e.g. despite more silicic acid, opal production declines further). The alkalinity change is more straightforward, since declining calcification decreases the export of alkalinity from the upper ocean driven by the so-called "hard tissues" component of the biological pump. Note that the seemingly small magnitude of alkalinity change is the result of a large background reservoir size.

In terms of fluxes, these are also broadly similar between the two simulations, but there are noticeable systematic differences. Calcification, while still down in RCP 8.5B relative to the $1990 \mathrm{~s}$, is much less impacted $(-17.5 \%$ versus $-55.6 \%$ ), and a major consequence of this lies - as implied previously - in the fate of the export flux. While this too is decreased in RCP 8.5B relative to the 1990s, it is much less so, and this reflects a greater penetration of $\mathrm{C}_{\text {org }}$ into the ocean interior, per MEDUSA-2.0's ballast submodel. In fact, both seafloor receipt and standing stock of $\mathrm{C}_{\text {org }}$ are elevated in RCP 8.5B relative to the 1990s. This change between RCP 8.5 and RCP $8.5 \mathrm{~B}$ suggests that a major biotic response to $\mathrm{OA}$ may be in the fate of benthic communities that may actually be isolated from the direct effects of OA. The panels of Fig. 21 illustrate this by showing the change in both $\mathrm{CaCO}_{3}$ production and $\mathrm{C}_{\text {org }}$ flux at $1000 \mathrm{~m}$ for RCP 8.5 and RCP $8.5 \mathrm{~B}$. Declines in both fields are much more pronounced in RCP 8.5 , and a strong correlation between both fluxes is clearly visible in the two simulations.

Finally, integrated over the course of the 21 st century, oceanic uptake of $\mathrm{CO}_{2}$ in RCP $8.5 \mathrm{~B}$ is slightly lower than that in RCP 8.5 ( $-2.2 \%$ of total uptake). Since both simulations
Table 4. Upper $100 \mathrm{~m}$ tracer concentrations, RCP 8.5B versus RCP 8.5 .

\begin{tabular}{llll}
\hline Field & $\begin{array}{l}\text { 1990s average } \\
\mathrm{mmol} \mathrm{m}^{-3}\end{array}$ & $\begin{array}{l}\Delta \text { 2090s, } \\
\text { RCP 8.5 \% }\end{array}$ & $\begin{array}{l}\Delta \text { 2090s, } \\
\text { RCP 8.5B \% }\end{array}$ \\
\hline Non-diatoms & 0.1796 & -1.74 & -1.29 \\
Diatoms & 0.0639 & -10.65 & -11.36 \\
Microzooplankton & 0.1017 & -4.03 & -3.23 \\
Mesozooplankton & 0.1152 & -9.11 & -10.18 \\
DIN & 8.669 & -8.40 & -7.33 \\
Silicic acid & 12.52 & -1.54 & +0.16 \\
Iron & 0.0006 & +1.23 & -2.87 \\
DIC & 2098 & +6.41 & +6.05 \\
Alkalinity & 2350 & +0.13 & -0.22 \\
Oxygen & 242.9 & -5.35 & -5.32 \\
\hline
\end{tabular}

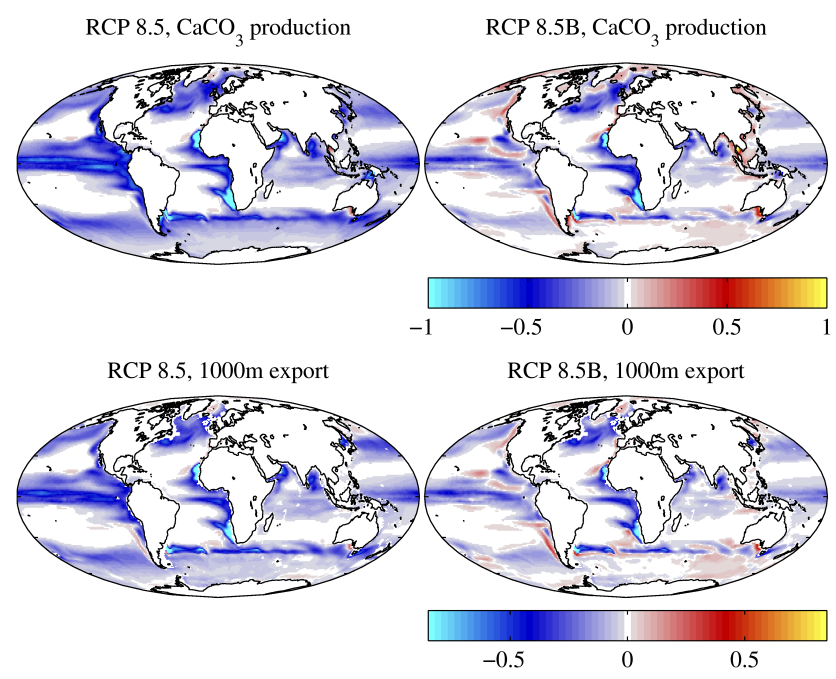

Fig. 21. Change between 1990s and 2090s biogenic $\mathrm{CaCO}_{3}$ production (top; mmol $\mathrm{Cm}^{-2} \mathrm{~d}^{-1}$ ) and export production at $1000 \mathrm{~m}$ (bottom; mmol $\mathrm{C} \mathrm{m}^{-2} \mathrm{~d}^{-1}$ ) for the RCP 8.5 (left) and RCP $8.5 \mathrm{~B}$ (right) simulations.

share a common climate, this effect stems from changes in ocean biogeochemistry. As noted above, RCP $8.5 \mathrm{~B}$ exhibits both lower production (primary and export) and lower surface alkalinity compared with RCP 8.5 , both of which act to decrease the ocean's absorption of $\mathrm{CO}_{2}$. The former by removing a direct source of $\mathrm{CO}_{2}$ consumption (and sequestration), the latter by decreasing the ocean's buffering capacity for DIC.

\section{Discussion}

Here we have described the application of an intermediate complexity ecosystem model, MEDUSA-2.0, to forecasting the future behaviour of ocean biogeochemistry under plausible future climates that span a broad range of implied human influence on the climate. Prior to quantifying 
Table 5. Major biogeochemical fluxes, RCP 8.5B versus RCP 8.5. Note that the $\Delta 2090$ s values shown for surface $\mathrm{pH}$ and $\Omega_{\text {calcite }}$ are instead 2090s values.

\begin{tabular}{|c|c|c|c|c|}
\hline Flux & Units & $\begin{array}{l}\text { 1990s } \\
\text { average }\end{array}$ & $\begin{array}{l}\Delta 2090 \mathrm{~s}, \\
\operatorname{RCP} 8.5 \%\end{array}$ & $\begin{array}{l}\Delta 2090 \mathrm{~s}, \\
\operatorname{RCP} 8.5 \mathrm{~B} \%\end{array}$ \\
\hline Primary production & ${\mathrm{PgC} \mathrm{yr}^{-1}}^{-1}$ & 41.83 & -6.07 & -6.89 \\
\hline Diatom fraction & $\%$ & 16.02 & -14.72 & -17.50 \\
\hline Opal production & Tmol Si yr $^{-1}$ & 195.8 & -5.71 & -5.93 \\
\hline $\mathrm{CaCO}_{3}$ production & $\mathrm{Tmol} \mathrm{C} \mathrm{yr}^{-1}$ & 34.96 & -55.57 & -17.52 \\
\hline Detritus production & ${\mathrm{PgC} \mathrm{yr}^{-1}}^{-1}$ & 28.65 & -7.63 & -8.89 \\
\hline Export, $100 \mathrm{~m}$ & $\mathrm{PgC}_{\mathrm{yr}}{ }^{-1}$ & 8.200 & -11.74 & -13.32 \\
\hline Export, $1000 \mathrm{~m}$ & ${\mathrm{PgC} \mathrm{yr}^{-1}}^{-1}$ & 0.3656 & -40.72 & -18.43 \\
\hline Export, seafloor & ${\mathrm{PgC} \mathrm{yr}^{-1}}^{-1}$ & 0.6604 & -6.47 & +5.42 \\
\hline Benthic $\mathrm{C}_{\text {org }}$ & $\mathrm{PgC}$ & 0.0608 & -3.88 & +4.11 \\
\hline Surface $\mathrm{pH}$ & - & 8.073 & 7.735 & 7.733 \\
\hline Surface $\Omega_{\text {calcite }}$ & - & 4.555 & 2.717 & 2.696 \\
\hline
\end{tabular}

future change, the performance of both MEDUSA-2.0 and its attendant physical model, NEMO, were evaluated for recent decades against a range of physical and biogeochemical properties. Although there were deficiencies in performance, for instance weak reproduction of surface chlorophyll and generally low ocean productivity, other aspects such as nutrient distributions and surface $\mathrm{CO}_{2}$ exchange provided sufficient credibility.

In simulating the changing ocean during the 21 st century, MEDUSA-2.0 estimated broadly declining trends in ocean productivity. While global scale change was a modest $-6 \%$ under the most extreme warming scenario, regionally this varied from $-21 \%$ in the Atlantic up to $+59 \%$ in the case of a newly ice-free Arctic. On this point, the collapse of the North Atlantic bloom in response to mixed layer depth shoaling and circulation changes is particularly notable, and, if accurate, would have significant socio-economic impacts. This change in ocean productivity was accompanied by a shift in the balance of production away from larger phytoplankton to smaller phytoplankton (diatom fraction: $13 \% \rightarrow 11 \%$ ), and with a smaller fraction of production occurring within the mixed layer in response to increasing ocean stratification (mixed layer fraction: $68 \% \rightarrow 64 \%$ ). Concommitantly, there was a decline in the production of important biominerals such as opal $(-6 \%)$ and calcium carbonate $(-55 \%)$, the latter impacted by both productivity changes and ocean acidification. Allied to the decline in organic production, and enhanced in MEDUSA-2. 0 by this drop in inorganic production, export production fell $(-8 \%)$, particularly that falling below $1000 \mathrm{~m}(-41 \%)$. In parallel, the volume of suboxic ocean waters increased by $13 \%$.

However, while the direction of most of these trends was the same under the more "optimistic" RCP 2.6 scenario, the scale of change was much less, and in some cases the trend was actually reversed. For instance, though declining until 2050 , Arctic sea ice recovers to $78 \%$ of its 2000 s value by the 2090s, and Antarctic sea ice actually slightly increases $(+0.7 \%)$. In the case of primary production, a decline under RCP $8.5(-6 \%)$ is a slight rise under RCP 2.6, although there are still declines in the diatom fraction and in opal and $\mathrm{CaCO}_{3}$ production.

In all of the above, attention was drawn to the impact of ocean acidification on modelled calcification - a decline of $-55 \%$ between the 1990 s and 2090 s. In the default simulation, MEDUSA-2.0 assumes a strong relationship between the saturation state of $\mathrm{CaCO}_{3}$ and its production by the biota, but a sensitivity simulation broke this link to investigate the consequences of this assumption (while retaining the connection for subsequent dissolution). This found that, though $\mathrm{CaCO}_{3}$ production still declined into the future $(-18 \%$; in part because of its link to organic production), its presence enhanced export production to the deep ocean (through the ballast submodel). Whereas this strongly declined in the default simulation $(-41 \%)$, in the sensitivity simulation it fell to a much lesser degree $(-18 \%)$. As a consequence, both seafloor receipt of organic material and benthic "biomass" were found to increase ( $+5 \%$; relative to the 1990 s) in this sensitivity simulation. Nonetheless, the results of both simulations illustrate a potential coupling of the efficiency of the ocean's biological pump to ocean acidification via the production of, and protection by, the biomineral $\mathrm{CaCO}_{3}$.

Comparing these results with those from other studies, in terms of ocean primary productivity, MEDUSA-2.0's decline into the future is consistent with a number of other model studies (Cox et al., 2000; Bopp et al., 2001, 2005; Steinacher et al., 2010). For example, in a review of four comparable models run under a similar future scenario, SRES A2 $\left(p \mathrm{CO}_{2}\right.$ $800 \mathrm{ppm}$ at 2100), Steinacher et al. (2010) found declines in primary production (between 2000 and 2095) of -1 to $-10 \%(-5 \%$ in the multi-model mean). In the same study, export production declines were found to range from -4 to $-16 \%$, in parallel with primary production, as found with 
MEDUSA-2.0. However, other studies have found decreased export production to instead be associated with increased primary production (Schmittner et al., 2008; Taucher and Oschlies, 2011).

In these latter models, temperature dependent parameterisations (cf. Eppley, 1972) and the elevated temperatures associated with climate change instead act to accelerate both primary production and remineralisation, with the result that nutrient trapping in the surface ocean fuels a large increase in regenerated production. In the case of Schmittner et al. (2008), production increases by approximately $+10 \%$ across the 21 st century, but ultimately almost doubles by the year 3000 . By running separate simulations with and without such temperature dependence, Taucher and Oschlies (2011) supports this interpretation. Nonetheless, MEDUSA2.0 's decrease in both primary and export production occurs despite temperature dependencies in both phytoplankton growth rates and (slow-sinking) detritus remineralisation that - in principle - parallel those of Schmittner et al. (2008). As such, more subtle differences in model function forms/parameters, or changes in less immediately obvious ecosystem pathways, may be responsible for this disparity, and merit further investigation.

One such subtlety may be the role played by biominerals in export, at least in MEDUSA-2.0. Here, shifts away from diatoms and opal production (see also Bopp et al., 2005), OA-driven decreases in $\mathrm{CaCO}_{3}$ production and a shallowing of the CCD, act to decrease the "protection" offered to fastsinking detrital particles, with the result that organic remineralisation occurs higher in the water column. As noted above, this has immediate implications for benthic communities reliant on organic rain from above, but the geographical interplay between upwelling nutrients, biomineralisation and detrital remineralisation may permit a broad range of responses from ostensibly the same general framework.

However, these factors - changes in $\mathrm{C}_{\text {org }}$, opal, $\mathrm{CaCO}_{3}$ and the CCD - do not act equally, and Fig. 22 shows an estimate of their separate impacts. Global average $\mathrm{C}_{\text {org }}$ flux down the water column is calculated by applying MEDUSA-2.0's ballast submodel to $100 \mathrm{~m}$ fluxes of $\mathrm{C}_{\text {org }}$, opal and $\mathrm{CaCO}_{3}$ in fast-sinking detritus (slow-sinking detritus is ignored here because it plays a limited role away from the surface ocean; but see below). Figure 22a first shows the change in the estimated normalised (to $100 \mathrm{~m}$ ) flux of $\mathrm{C}_{\text {org }}$ from the 1980s through to 2100 . As described previously, the attenuation of this flux changes significantly across the 21 st century. Fig. $22 b$ then shows the profile of normalised flux for the 1990s, the 2090s and for four variants of the 2090s in which 1990s $\mathrm{C}_{\text {org }}$, opal, $\mathrm{CaCO}_{3}$ and the $\mathrm{CCD}$ are substituted for their 2090s values. The intention being to determine which of these is most responsible for the decline seen in Fig. 22a. To supplement this, Table 6 reports the estimated values of fast-sinking detritus at horizons down the water column for the same calculations, with the final row reporting the flux of organic carbon at $5000 \mathrm{~m}$ normalised to that at $100 \mathrm{~m}$. This
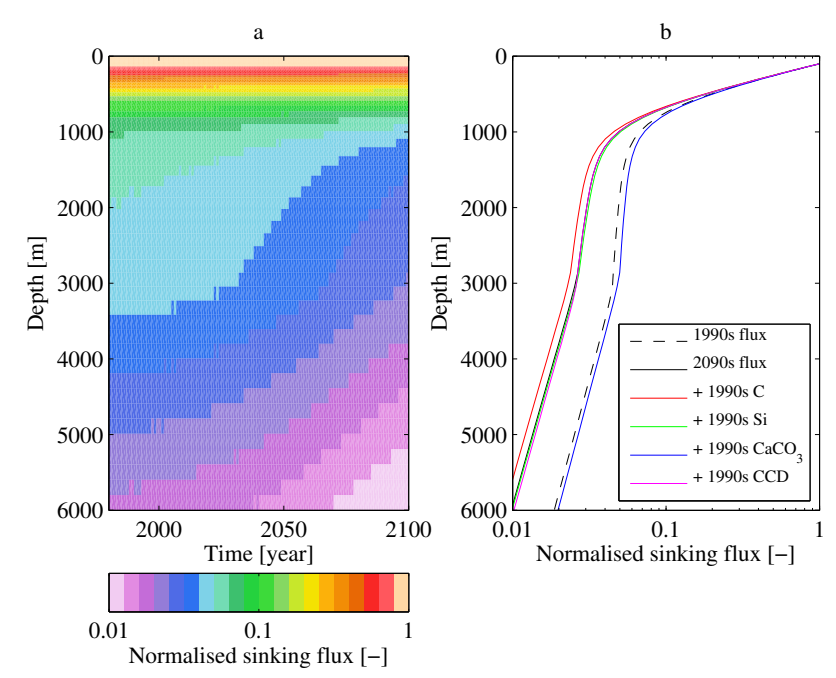

Fig. 22. Change in the vertical profile of normalised attenuation of fast-sinking detritus for the period 1980-2100 (left), and the attribution of this to changes in regulating factors (right). In the latter panel, artificial profiles of 2090s attenuation are created by the substitution of 1990s fields of Corg, opal, $\mathrm{CaCO}_{3}$ and $\mathrm{CCD}$ depth.

analysis finds that the dominant factor in the change in the deep flux of organic carbon over the 21st century is the loss of ballasting $\mathrm{CaCO}_{3}$. Opal and the $\mathrm{CCD}$ play very minor roles and the "starting" flux of organic carbon plays practically no role, since the ballast submodel quickly attenuates the excess $1990 \mathrm{~s} \mathrm{C}_{\text {org }}$ (to the point that the normalised flux at $5000 \mathrm{~m}$ is lower than the case using $2090 \mathrm{~s}_{\mathrm{org}}$ ). As such, this further emphasises the importance of understanding both the veracity of export submodels based around ballasting and OA impacts on a key driver of these, calcification.

Note that the situation is slightly more complicated in shallow regions of the ocean, where slow-sinking detritus can persist long enough to reach the seafloor, and can make an important contribution to benthic supply of organic carbon. In these regions, elevated ocean temperatures in the future act to increase the rate of remineralisation to provide a separate mechanism by which the food supply to benthic communities is decreased.

By way of representing how these changes relate to natural, or background, variability in export production, Fig. 23 illustrates spatial variability and how this changes between the 1990s and 2090s. Here, export is characterised by calculating the critical $b$ parameter of Martin et al. (1987), which effectively sets the exponential decay of sinking organic carbon and the vertical pattern of remineralisation. While originally assigned a constant value, 0.858 , from a relatively limited dataset, subsequent work has found $b$ to be significantly geographically variable - for example, Buesseler et al. (2007) report values of 1.33 and 0.51 for neighbouring North Pacific sites, while the global synthesis of Henson et al. (2012) reports a broad geographical range from 0.24 to 
Table 6. Calculated carbon fluxes (mmol m $\mathrm{m}^{-2} \mathrm{~d}^{-1}$ ) based on $100 \mathrm{~m} \mathrm{C}_{\text {org }}$, opal and $\mathrm{CaCO}_{3}$ fluxes and CCD depth. Fluxes extrapolated to ocean interior depths using MEDUSA-2.0 ballast submodel. “+ 1990s” columns refer to fluxes calculated using 2090s values except for the indicated and replaced value. The final row lists the $5000 \mathrm{~m}$ carbon flux normalised to the $100 \mathrm{~m}$ flux.

\begin{tabular}{lllllll}
\hline $\begin{array}{l}\text { Depth } \\
\mathrm{m}\end{array}$ & $\begin{array}{l}1990 \mathrm{~s} \\
\mathrm{mmol} \mathrm{m}\end{array}$ & $\begin{array}{l}2090 \mathrm{~s} \\
\mathrm{mmol} \mathrm{m} \mathrm{d}^{-1} \mathrm{~d}^{-1}\end{array}$ & $\begin{array}{l}+1990 \mathrm{~s} \mathrm{C}_{\mathrm{org}} \\
\mathrm{mmol} \mathrm{m}^{-2} \mathrm{~d}^{-1}\end{array}$ & $\begin{array}{l}+1990 \mathrm{~s} \mathrm{Si} \\
\mathrm{mmol} \mathrm{m}^{-2} \mathrm{~d}^{-1}\end{array}$ & $\begin{array}{l}+1990 \mathrm{saCO}_{3} \\
\mathrm{mmol} \mathrm{m}^{-2} \mathrm{~d}^{-1}\end{array}$ & $\begin{array}{l}+1990 \mathrm{~s} \mathrm{CCD} \\
\mathrm{mmol} \mathrm{m}^{-2} \mathrm{~d}^{-1}\end{array}$ \\
\hline 100 & 4.0220 & 3.6110 & 4.0220 & 3.6110 & 3.6110 & 3.6110 \\
200 & 2.5000 & 2.2181 & 2.4637 & 2.2205 & 2.2521 & 2.2181 \\
500 & 0.7159 & 0.5852 & 0.6375 & 0.5900 & 0.6588 & 0.5852 \\
1000 & 0.2498 & 0.1584 & 0.1618 & 0.1627 & 0.2420 & 0.1584 \\
2000 & 0.1965 & 0.1093 & 0.1093 & 0.1122 & 0.1936 & 0.1093 \\
5000 & 0.0960 & 0.0458 & 0.0458 & 0.0464 & 0.0912 & 0.0477 \\
\hline 5000 & 0.0239 & 0.0127 & 0.0114 & 0.0129 & 0.0253 & 0.0132 \\
\hline
\end{tabular}
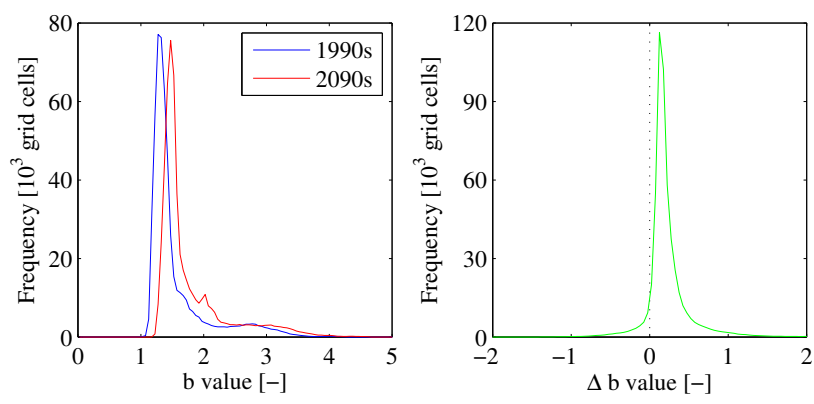

Fig. 23. Frequency distribution of Martin et al. (1987) $b$ parameter values estimated from the $100 \mathrm{~m}$ and $1000 \mathrm{~m}$ fluxes of slow- and fast-sinking detritus for the 1990s and 2090s (left), and the distribution of differences between the 2090s and 1990s (right).

1.18. Based on the change in total (slow- and fast-sinking) organic carbon fluxes between $100 \mathrm{~m}$ and $1000 \mathrm{~m}$, and weighting spatially by flux magnitude, MEDUSA- 2.0 has a average $b$ of 1.342 in the $1990 \mathrm{~s}$, and 1.524 in the 2090s. To illustrate variability, Fig. 23a shows the spread of simulated $b$ values for both the 1990s and 2090s, while Fig. 23b shows the corresponding distribution of change in $b$ across the 21 st century. In MEDUSA-2.0, $b$ has a peaked, non-unimodal distribution, that broadly persists but shifts upwards between the 1990s and 2090s. This is congruent with results above that the sinking flux of organic material is attenuated more rapidly with depth into the future. The mode change in $b$ across the 21 st century is 0.125 , though it ranges widely, and some regions experience a decrease in $b-$ i.e. a larger proportion, but not necessarily a larger absolute amount, of sinking material reaches deeper into the ocean interior. This change is dependent on MEDUSA-2.0's use of both temperature-dependent remineralisation of slow-sinking detritus and ballast-based export remineralisation.

As already suggested above, there are a number of caveats concerning these results.

Firstly, as illustrated by the validation exercise, MEDUSA-2.0 exhibits a number of deficiencies in its spatio-temporal reproduction of biogeochemistry. While some of these, for instance surface chlorophyll, reflect weaknesses in MEDUSA-2.0 itself, others, for instance deep nutrient mismatches, are (at least in part) the result of problems with the ocean circulation simulated by NEMO (see Yool et al., 2013).

Secondly, some of the more interesting results found are dependent on MEDUSA-2.0's parameterisation of $\mathrm{CaCO}_{3}$ production (cf. Ridgwell et al., 2007). This explicitly links calcification (or, rather, its export) to the saturation state of this biomineral and, thus, ocean acidification (cf. Riebesell et al., 2000; Zondervan et al., 2001). However, as a number of observational and laboratory studies have shown, the relationship between calcification and $\mathrm{OA}$ is more diverse than assumed in MEDUSA-2.0 (e.g. Buitenhuis et al., 1999; Langer et al., 2006; Iglesias-Rodriguez et al., 2008). As such, the modelled decline of $\mathrm{CaCO}_{3}$ here (which is also found in other models; e.g. Heinze, 2004; Gehlen et al., 2007) may ultimately prove oversimplified or artifactual. Note, however, that MEDUSA-2.0's equating of $\mathrm{CaCO}_{3}$ with calcite rather than the less stable polymorph aragonite potentially acts to make the model more conservative on this point.

Thirdly, and on a directly related point, the resulting changes in export production depend in large part on the assumption of a regulatory role for biominerals in the fate of sinking material. MEDUSA-2.0 includes the widely used ballast submodel (e.g. Moore et al., 2004; Dunne et al., 2007; Oka et al., 2008) which effectively allows biominerals associated with sinking particles to "protect" them from remineralisation, allowing a deeper penetration of organic detritus to the ocean interior. However, work such as Wilson et al. (2012) finds that this relationship with biominerals exhibits geographical variability, and suggests that it may not be a robust one. Furthermore, the experimental study of Passow and De La Rocha (2006) suggests a different relationship between sinking organic and inorganic material to that postulated by Armstrong et al. (2002). As such, the exaggerated decline of organic supply to the deep ocean found 
by MEDUSA-2.0 may overstate future behaviour in the real world.

Finally, MEDUSA-2.0 is an intermediate complexity model that aims to resolve major biogeochemical actors and fluxes, but it omits a large number of others. In particular, unresolved processes such as denitrification and nitrogen fixation are liable to change in the future (Moore and Doney, 2007) with the potential to alter nutrient availability and ocean productivity in ways that cannot be captured by MEDUSA-2.0. While these omissions are deliberate and reflect either the assumed lesser importance of such processes or our comparative ignorance of their details (cf. Anderson, 2005), they nonetheless represent a truncation of reality and a limitaton on the diversity of future change that MEDUSA2.0 can forecast.

\section{Conclusions}

- Surface macronutrient concentrations broadly decline into the future as their resupply from deeper waters is impeded by increased water column stratification; this is particularly true of the North Atlantic.

- In contrast, the surface concentrations of the micronutrient iron increase significantly in the North Atlantic as primary production is limited more by macronutrient concentrations; however, most other ocean regions experience a decline in surface iron.

- With the exception of the Arctic Ocean, all regions of the World Ocean experience declines in productivity associated with decreased nutrient availability, with the Atlantic Ocean. particularly impacted; productivity generally shifts to below the mixed layer and away from that driven by diatoms

- Near-surface export production declines broadly in line with primary production; however, because of the concurrent decrease in ballasting "protection" and the shoaling of $\mathrm{CaCO}_{3}$ dissolution, the amount of sinking detrital material decreases above and beyond the production decline, increasingly so with depth and with potential consequences for seafloor communities.

- Scenario RCP 2.6 experiences significant (but stabilised) warming, but changes to ocean biogeochemistry are minor relative to those under RCP 8.5 ; ocean productivity is even marginally increased in the 2090s relative to the 1990s, though ocean acidification impacts are still evident.

- The reliance of certain key results on particular features of MEDUSA-2.0's formulation suggests improving understanding of poorly constrained processes will be critical for accurate forecasts of the ocean's biogeochemical cycles during this century's unprecedented change.
Table A1. MEDUSA-2.0 state variables.

\begin{tabular}{lll}
\hline \multicolumn{3}{l}{ The full list of 3D water column state variables is as follows: } \\
\hline $\mathrm{Pn}$ & Non-diatom phytoplankton & $\mathrm{mmol} \mathrm{N} \mathrm{m}^{-3}$ \\
$\mathrm{Pd}$ & Diatom phytoplankton & $\mathrm{mmol} \mathrm{N} \mathrm{m}^{-3}$ \\
$\mathrm{Ch}_{\mathrm{Pn}}$ & Chlorophyll in non-diatoms & $\mathrm{mg} \mathrm{chl} \mathrm{m}^{-3}$ \\
$\mathrm{Ch}_{\mathrm{Pd}}$ & Chlorophyll in diatoms & $\mathrm{mg} \mathrm{chl} \mathrm{m}^{-3}$ \\
$\mathrm{Pd}$ & Diatom phytoplankton (silicon) & $\mathrm{mmol} \mathrm{Si} \mathrm{m}^{-3}$ \\
$\mathrm{Z} \mu$ & Microzooplankton & $\mathrm{mmol} \mathrm{N} \mathrm{m}^{-3}$ \\
$\mathrm{Zm}$ & Mesozooplankton & $\mathrm{mmol} \mathrm{N} \mathrm{m}^{-3}$ \\
$\mathrm{D}$ & Slow-sinking detritus (N) & $\mathrm{mmol} \mathrm{N} \mathrm{m}^{-3}$ \\
$\mathrm{D}_{\mathrm{C}}$ & Slow-sinking detritus (C) & $\mathrm{mmol} \mathrm{C} \mathrm{m}^{-3}$ \\
$\mathrm{~N}$ & Nitrogen nutrient & $\mathrm{mmol} \mathrm{N} \mathrm{m}^{-3}$ \\
$\mathrm{~S}$ & Silicic acid & $\mathrm{mmol} \mathrm{Si} \mathrm{m}^{-3}$ \\
$\mathrm{~F}$ & Iron nutrient & $\mathrm{mmol} \mathrm{Fe} \mathrm{m}^{-3}$ \\
$\mathrm{DIC}$ & Dissolved inorganic carbon & $\mathrm{mmol} \mathrm{C} \mathrm{m}^{-3}$ \\
$\mathrm{ALK}$ & Total alkalinity & $\mathrm{meq} \mathrm{m}^{-3}$ \\
$\mathrm{O}_{2}$ & Dissolved oxygen & $\mathrm{mmol} \mathrm{O}_{2} \mathrm{~m}^{-3}$ \\
\hline $\mathrm{The}$ full list of 2-D benthic state variables & represented is as follows: \\
\hline $\mathrm{B}_{\mathrm{N}}$ & Benthic organic nitrogen & $\mathrm{mmol} \mathrm{N} \mathrm{m}^{-2}$ \\
$\mathrm{~B}_{\mathrm{C}}$ & Benthic organic carbon & $\mathrm{mmol} \mathrm{N} \mathrm{m}^{-2}$ \\
$\mathrm{~B}_{\mathrm{Si}}$ & Benthic inorganic silicon & $\mathrm{mmol} \mathrm{Si} \mathrm{m}^{-2}$ \\
$\mathrm{~B}_{\mathrm{Ca}}$ & Benthic inorganic CaCO & $\mathrm{mmol} \mathrm{C} \mathrm{m}_{3}^{-2}$ \\
\hline
\end{tabular}

\section{Appendix A}

\section{MEDUSA-2.0 equations}

The following partial differential equations describe the biogeochemical tendency terms that operate on MEDUSA-2.0's state variables. Beneath each term there is a brief description of the process that it represents. The abbreviations used in these descriptions are: "PP" for primary production; " $\mu$ zoo" for microzooplankton; "mzoo" for mesozooplankton; "nonlin" for non-linear; "remin" for remineralisation of organic material; and "diss" for dissolution of inorganic biominerals (e.g. opal or $\mathrm{CaCO}_{3}$ ). Almost all of the terms shown refer to more complex functions not described in this manuscript, and readers are referred to Yool et al. (2013) for further details. Note that the equations below omit reference to physical operators such as advection and diffusion.

$$
\begin{aligned}
\frac{\partial \mathrm{Pn}}{\partial t}= & +\underbrace{\left[\mathrm{PP} P_{\mathrm{Pn}} \cdot \mathrm{Pn}\right]}_{\text {non-diatom PP }}-\underbrace{\left[\mathrm{G} \mu_{\mathrm{Pn}}\right]}_{\mu \mathrm{zoo} \mathrm{graze}}-\underbrace{\left[\mathrm{Gm} \mathrm{Pn}_{\mathrm{Pn}}\right]}_{\text {mzoo graze }} \\
& -\underbrace{\left[\mathrm{M} 1_{\mathrm{Pn}}\right]}_{\text {linear losses }}-\underbrace{\left[\mathrm{M} 2_{\mathrm{Pn}}\right]}_{\text {non-lin losses }} \\
\frac{\partial \mathrm{Pd}}{\partial t}= & +\underbrace{\left[\mathrm{PP} \mathrm{Pd}_{\mathrm{Pd}} \cdot \mathrm{Pd}\right]}_{\text {diatom PP }}-\underbrace{\left[\mathrm{Gm} \mathrm{Pd}_{\mathrm{Pd}}\right]}_{\text {mzoo graze }}-\underbrace{\left[\mathrm{M} 1_{\mathrm{Pd}}\right]}_{\text {linear losses }} \\
& -\underbrace{\left[\mathrm{M} 2_{\mathrm{Pd}}\right]}_{\text {non-lin losses }}
\end{aligned}
$$




$$
\begin{aligned}
\frac{\partial \mathrm{Chl}_{\mathrm{Pn}}}{\partial t}= & \theta_{\mathrm{Pn}} \mathrm{Chl}^{-1} \cdot(+\underbrace{\left[R_{\mathrm{Pn}} \cdot \mathrm{PP}_{\mathrm{Pn}} \cdot \mathrm{Pn}\right]}_{\text {non-diatom PP }} \\
& -\underbrace{\left[\mathrm{G} \mu_{\mathrm{Pn}}\right]}_{\text {uzoo graze }}-\underbrace{[\mathrm{Gm} \underbrace{}_{\text {Pn }}]}_{\text {mzoo graze }}-\underbrace{\left[\mathrm{M} 1_{\mathrm{Pn}}\right]}_{\text {linear losses }} \\
& -\underbrace{[\mathrm{M} 2 \mathrm{Pn}]}_{\text {non-lin losses }}]
\end{aligned}
$$

$\frac{\partial \mathrm{Chl}_{\mathrm{Pd}}}{\partial t}=\theta_{\mathrm{Pd}}^{\mathrm{Chl}} \cdot \xi^{-1} \cdot(+\underbrace{\left[R_{\mathrm{Pd}} \cdot \mathrm{PP}_{\mathrm{Pd}} \cdot \mathrm{Pd}\right]}_{\text {diatom PP }}$

$$
-\underbrace{\left[\mathrm{Gm}_{\mathrm{Pd}}\right]}_{\text {mzoo graze }}-\underbrace{\left[\mathrm{M} 1_{\mathrm{Pd}}\right]}_{\text {linear losses }}-\underbrace{\left[\mathrm{M} 2_{\mathrm{Pd}}\right]}_{\text {non-lin losses }})
$$

$$
\begin{aligned}
& \frac{\partial \mathrm{Pd}_{\mathrm{Si}}}{\partial t}=+\underbrace{\left[\mathrm{PP}_{\mathrm{Pd}_{\mathrm{Si}}} \cdot \mathrm{Pd}_{\mathrm{Si}}\right]}_{\text {diatom PP }}-\underbrace{\left[\mathrm{Gm}_{\mathrm{Pd}_{\mathrm{Si}}}\right]}_{\text {mzoo graze }}-\underbrace{\left[\mathrm{M}_{\mathrm{Pd}_{\mathrm{Si}}}\right]}_{\text {linear losses }} \\
& -\underbrace{\left[\mathrm{M}_{\mathrm{Pd}_{\mathrm{Si}}}\right]}_{\text {non-lin losses }}-\underbrace{\left[\mathrm{DS}_{\mathrm{Pd}_{\mathrm{Si}}}\right]}_{\text {dissolution }}
\end{aligned}
$$

$$
\frac{\partial \mathrm{Z} \mu}{\partial t}=+\underbrace{\left[F_{\mathrm{Z} \mu}\right]}_{\text {all grazing }}-\underbrace{\left[\mathrm{Gm}_{\mathrm{Z} \mu}\right]}_{\text {mzoo graze }}-\underbrace{\left[\mathrm{M} 1_{\mathrm{Z} \mu}\right]}_{\text {linear losses }}
$$

$$
-\underbrace{[\mathrm{M} 2 \mathrm{Z \mu}]}_{\text {non-lin losses }}
$$

$$
\frac{\partial \mathrm{Zm}}{\partial t}=+\underbrace{\left[F_{\mathrm{Zm}}\right]}_{\text {all grazing }}-\underbrace{\left[\mathrm{M} 1_{\mathrm{Zm}}\right]}_{\text {linear losses }}-\underbrace{\left[\mathrm{M} 2_{\mathrm{Zm}}\right]}_{\text {non-lin losses }}
$$

$$
\frac{\partial \mathrm{D}}{\partial t}=+\underbrace{\left[\mathrm{M} 22_{\mathrm{Pn}}\right]}_{\text {non-diatom losses }}+\underbrace{[\mathrm{M} 2 \mathrm{Z \mu}]}_{\mu \text { zoo losses }}
$$

$$
+\underbrace{\left[\left(1-\mathrm{D} 1_{\text {frac }}\right) \cdot \mathrm{M} 2_{\mathrm{Pd}}\right]}_{\text {diatom losses }}
$$$$
+\underbrace{\left[\left(1-\mathrm{D} 2_{\mathrm{frac}}\right) \cdot \mathrm{M} 2_{\mathrm{Zm}}\right]}_{\text {mzoo losses }}
$$$$
+\underbrace{\left[\left(1-\beta_{\mathrm{N}}\right) \cdot \mathrm{IN}_{\mathrm{Z \mu}}\right]}_{\mu \text { zoo egestion }}+\underbrace{\left[\left(1-\beta_{\mathrm{N}}\right) \cdot \mathrm{IN}_{\mathrm{Zm}}\right]}_{\text {mzoo egestion }}
$$$$
-\underbrace{\left[\mathrm{G} \mu_{\mathrm{D}}\right]}_{\mu \text { zoo graze }}-\underbrace{\left[\mathrm{Gm}_{\mathrm{D}}\right]}_{\text {mzoo graze }}-\underbrace{\left[\mathrm{M}_{\mathrm{D}}\right]}_{\text {remin }}-\underbrace{\left[w_{\mathrm{g}} \cdot \frac{\partial \mathrm{D}}{\partial z}\right]}_{\text {sinking }}
$$

$$
\frac{\partial \mathrm{D}_{\mathrm{C}}}{\partial t}=+\underbrace{\left[\theta_{\mathrm{Pn}} \cdot \mathrm{M} 2_{\mathrm{Pn}}\right]}_{\text {non-diatom losses }}+\underbrace{\left[\theta_{\mathrm{Z} \mu} \cdot \mathrm{M} 2_{\mathrm{Z} \mu}\right]}_{\mu \text { zoo losses }}
$$

$$
\begin{aligned}
& +\underbrace{\left[\theta_{\mathrm{Pd}} \cdot\left(1-\mathrm{D} 1_{\text {frac }}\right) \cdot \mathrm{M} 2_{\mathrm{Pd}}\right]}_{\text {diatom losses }} \\
& +\underbrace{\left[\theta_{\mathrm{Zm}} \cdot\left(1-\mathrm{D} 2_{\mathrm{frac}}\right) \cdot \mathrm{M} 2_{\mathrm{Zm}}\right]}_{\text {mzoo losses }} \\
& +\underbrace{\left[\left(1-\beta_{\mathrm{C}}\right) \cdot \mathrm{IC}_{\mathrm{Z \mu}}\right]}_{\mu \text { zoo egestion }}+\underbrace{\left[\left(1-\beta_{\mathrm{C}}\right) \cdot \mathrm{IC}_{\mathrm{Zm}}\right]}_{\text {mzoo egestion }} \\
& -\underbrace{\left[\mathrm{G} \mu_{\text {Dc }}\right]}_{\mu \text { zoo graze }}-\underbrace{\left[\mathrm{Gm} m_{\text {Dc }}\right]}_{\text {mzoo graze }}-\underbrace{\left[\mathrm{M}_{\mathrm{Dc}}\right]}_{\text {remin }}-\underbrace{\left[w_{\mathrm{g}} \cdot \frac{\partial \mathrm{D}_{\mathrm{C}}}{\partial z}\right]}_{\text {sinking }} \\
& \frac{\partial \mathrm{N}}{\partial t}=-\underbrace{\left[\mathrm{PP}_{\mathrm{Pn}} \cdot \mathrm{Pn}\right]}_{\text {non-diatom PP }}-\underbrace{\left[\mathrm{PP}_{\mathrm{Pd}} \cdot \mathrm{Pd}\right]}_{\text {diatom PP }} \\
& +\underbrace{\left[\phi \cdot\left(\mathrm{G} \mu_{\mathrm{Pn}}+\mathrm{G} \mu_{\mathrm{D}}\right)\right]}_{\mu \text { zoo messy feeding }} \\
& +\underbrace{\left[\phi \cdot\left(\mathrm{Gm}_{\mathrm{Pn}}+\mathrm{Gm}_{\mathrm{Pd}}+\mathrm{Gm}_{\mathrm{Z} \mu}+\mathrm{Gm}_{\mathrm{D}}\right)\right]}_{\text {mzoo messy feeding }} \\
& +\underbrace{\left[E_{\mathrm{Z} \mu}\right]}_{\mu \mathrm{zoo} \text { excretion }}+\underbrace{\left[E_{\mathrm{Zm}}\right]}_{\text {mzoo excretion }} \\
& +\underbrace{\left[\mathrm{M} 1_{\mathrm{Pn}}\right]}_{\text {non-diatom losses }}+\underbrace{\left[\mathrm{M} 1_{\mathrm{Pd}}\right]}_{\text {diatom losses }}+\underbrace{\left[\mathrm{M} 1_{\mathrm{Z} \mu}\right]}_{\mu \mathrm{zoo} \text { losses }} \\
& +\underbrace{\left[\mathrm{M} 1_{\mathrm{Zm}}\right]}_{\text {mzoo losses }}+\underbrace{\left[\mathrm{M}_{\mathrm{D}}\right]}_{\text {remin }}+\underbrace{\left[\mathrm{LD}_{\mathrm{N}}(k)\right]}_{\text {fast N remin }} \\
& +\underbrace{\left[\mathrm{BF}_{\mathrm{N}}\right]}_{\text {benthic remin }} \\
& \frac{\partial \mathrm{S}}{\partial t}=-\underbrace{\left[\mathrm{PP}_{\mathrm{Pd}_{\mathrm{Si}}} \cdot \mathrm{Pd}_{\mathrm{Si}}\right]}_{\text {diatom PP }}+\underbrace{\left[\mathrm{M}_{\mathrm{Pd}_{\mathrm{Si}}}\right]}_{\text {linear losses }} \\
& +\underbrace{\left[\left(1-\mathrm{D} 1_{\text {frac }}\right) \cdot \mathrm{M} 2_{\mathrm{Pd}_{\mathrm{Si}}}\right]}_{\text {non-lin. losses }}+\underbrace{\left[\mathrm{DS}_{\mathrm{Pd}_{\mathrm{Si}}}\right]}_{\text {dissolution }} \\
& +\underbrace{\left[\left(1-\mathrm{D} 2_{\text {frac }}\right) \cdot \mathrm{Gm}_{\mathrm{Pd}_{\mathrm{Si}}}\right]}_{\text {mzoo graze }}+\underbrace{\left[\mathrm{LD}_{\mathrm{Si}}(k)\right]}_{\text {fast Si detritus diss }} \\
& +\underbrace{\left[\mathrm{BF}_{\mathrm{Si}}\right]}_{\text {benthic diss }} \\
& \frac{\partial \mathrm{F}}{\partial t}=-\underbrace{\left[R_{\mathrm{Fe}} \cdot \frac{\partial \mathrm{N}}{\partial t}\right]}_{\text {coupled to } \mathrm{N}}+\underbrace{\left[F_{\text {atmos }}\right]}_{\text {aeolian }}+\underbrace{\left[F_{\text {benth }}\right]}_{\text {sediments }} \\
& -\underbrace{\left[F_{\text {scavenge }}\right]}_{\text {scavenging }}+\underbrace{\left[\mathrm{BF}_{\mathrm{Fe}}\right]}_{\text {benthic remin }} \\
& \frac{\partial \mathrm{DIC}}{\partial t}=-\underbrace{\left[\theta_{\mathrm{Pn}} \cdot \mathrm{PP}_{\mathrm{Pn}} \cdot \mathrm{Pn}\right]}_{\text {non-diatom PP }}-\underbrace{\left[\theta_{\mathrm{Pd}} \cdot \mathrm{PP}_{\mathrm{Pd}} \cdot \mathrm{Pd}\right]}_{\text {diatom PP }} \\
& +\underbrace{\left[\phi \cdot \theta_{\mathrm{Pn}} \cdot \mathrm{G} \mu_{\mathrm{Pn}}\right]}_{\mu \text { zoo messy feeding, Pn }}+\underbrace{\left.\left[\phi \cdot \mathrm{G} \mu_{\mathrm{Dc}}\right)\right]}_{\mu \text { zoo messy feeding, Dc }}
\end{aligned}
$$




$$
\begin{aligned}
& +\underbrace{\left[\phi \cdot \theta_{\mathrm{Pn}} \cdot \mathrm{Gm}_{\mathrm{Pn}}\right]}_{\text {mzoo messy feeding, Pn }}+\underbrace{\left[\phi \cdot \theta_{\mathrm{Pd}} \cdot \mathrm{Gm}_{\mathrm{Pd}}\right]}_{\text {mzoo messy feeding, Pd }} \\
& +\underbrace{\left[\phi \cdot \theta_{\mathrm{Z} \mu} \cdot \mathrm{Gm}_{\mathrm{Z} \mu}\right]}_{\text {mzoo messy feeding, } \mathrm{Z} \mu}+\underbrace{\left.\left[\phi \cdot \mathrm{Gm}_{\mathrm{Dc}}\right)\right]}_{\text {mzoo messy feeding, Dc }} \\
& +\underbrace{\left[R_{\mathrm{Z} \mu}\right]}_{\mu \text { zoo respiration }}+\underbrace{\left[R_{\mathrm{Zm}}\right]}_{\text {mzoo respiration }} \\
& +\underbrace{\left[\theta_{\mathrm{Pn}} \cdot \mathrm{M} 1_{\mathrm{Pn}}\right]}_{\text {non-diatom losses }}+\underbrace{\left[\theta_{\mathrm{Pd}} \cdot \mathrm{M} 1_{\mathrm{Pd}}\right]}_{\text {diatom losses }} \\
& +\underbrace{\left[\theta_{\mathrm{Z} \mu} \cdot \mathrm{M}_{\mathrm{Z} \mu}\right]}_{\mu \text { zoo losses }}+\underbrace{\left[\theta_{\mathrm{Zm}} \cdot \mathrm{M}_{\mathrm{Zm}}\right]}_{\text {mzoo losses }} \\
& +\underbrace{\left[\mathrm{M}_{\mathrm{Dc}}\right]}_{\text {remin }}+\underbrace{\left[\mathrm{LD}_{\mathrm{C}}(k)\right]}_{\text {fast } \mathrm{C} \text { remin }} \\
& -\underbrace{\left[\mathrm{FD}_{\mathrm{CaCO}_{3}}\right]}_{\mathrm{CaCO}_{3} \text { production }}+\underbrace{\left[\mathrm{LD}_{\mathrm{CaCO}_{3}}(k)\right]}_{\mathrm{CaCO}_{3} \text { diss }} \\
& +\underbrace{[\mathrm{BF} \mathrm{C}]}_{\text {benthic remin }}+\underbrace{\left[A S F_{\mathrm{CO}_{2}}\right]}_{\text {air-sea gas exchange }} \\
& \frac{\partial \mathrm{ALK}}{\partial t}=-\underbrace{\left[2 \cdot \mathrm{FD}_{\mathrm{CaCO}_{3}}\right]}_{\mathrm{CaCO}_{3} \text { production }}+\underbrace{\left[2 \cdot \mathrm{LD}_{\mathrm{CaCO}_{3}}(k)\right]}_{\mathrm{CaCO}_{3} \text { diss }} \\
& +\underbrace{\left[\mathrm{BF}_{\mathrm{CaCO}_{3}}\right]}_{\text {benthic diss }} \\
& \frac{\partial \mathrm{O}_{2}}{\partial t}=+\underbrace{\left[\theta_{\text {nit }} \cdot \mathrm{PP}_{\mathrm{Pn}} \cdot \mathrm{Pn}\right]}_{\text {non-diatom PP }}+\underbrace{\left[\theta_{\text {nit }} \cdot \mathrm{PP}_{\mathrm{Pd}} \cdot \mathrm{Pd}\right]}_{\text {diatom PP }} \\
& -\underbrace{\left[\theta_{\text {nit }} \cdot \phi \cdot \mathrm{G} \mu_{\mathrm{Pn}}\right]}_{\mu \text { zoo messy feeding, Pn }}-\underbrace{\left.\left[\theta_{\text {nit }} \cdot \phi \cdot \mathrm{G} \mu_{\mathrm{D}}\right)\right]}_{\mu \text { zoo messy feeding, Dc }} \\
& -\underbrace{\left[\theta_{\text {nit }} \cdot \phi \cdot \mathrm{Gm}_{\mathrm{Pn}}\right]}_{\text {mzoo messy feeding, Pn }}-\underbrace{\left[\theta_{\text {nit }} \cdot \phi \cdot \mathrm{Gm}_{\mathrm{Pd}}\right]}_{\text {mzoo messy feeding, Pd }} \\
& -\underbrace{\left[\theta_{\text {nit }} \cdot \phi \cdot \mathrm{Gm}_{\mathrm{Z} \mu}\right]}_{\text {mzoo messy feeding, } \mathrm{Z} \mu}-\underbrace{\left.\left[\theta_{\text {nit }} \cdot \phi \cdot \mathrm{Gm}_{\mathrm{D}}\right)\right]}_{\text {mzoo messy feeding, Dc }} \\
& -\underbrace{\left[\theta_{\text {nit }} \cdot E_{\mathrm{Z} \mu}\right]}_{\mu \text { zoo excretion }}-\underbrace{\left[\theta_{\text {nit }} \cdot E_{\mathrm{Zm}}\right]}_{\text {mzoo excretion }} \\
& -\underbrace{\left[\theta_{\text {nit }} \cdot \mathrm{M} 1_{\mathrm{Pn}}\right]}_{\text {non-diatom losses }}-\underbrace{\left[\theta_{\text {nit }} \cdot \mathrm{M} 1_{\mathrm{Pd}}\right]}_{\text {diatom losses }} \\
& -\underbrace{\left[\theta_{\text {nit }} \cdot \mathrm{M} 1_{\mathrm{Z} \mu}\right]}_{\mu \text { zoo losses }}-\underbrace{\left[\theta_{\text {nit }} \cdot \mathrm{M} 1_{\mathrm{Zm}}\right]}_{\text {mzoo losses }} \\
& -\underbrace{\left[\theta_{\text {nit }} \cdot \mathrm{M}_{\mathrm{D}}\right]}_{\text {remin }}-\underbrace{\left[\theta_{\text {nit }} \cdot \mathrm{LD}_{\mathrm{N}}(k)\right]}_{\text {fast } \mathrm{N} \text { remin }} \\
& +\underbrace{\left[\theta_{\text {rem }} \cdot \theta_{\mathrm{Pn}} \cdot \mathrm{PP}_{\mathrm{Pn}} \cdot \mathrm{Pn}\right]}_{\text {non-diatom PP }} \\
& +\underbrace{\left[\theta_{\text {rem }} \cdot \theta_{\mathrm{Pd}} \cdot \mathrm{PP}_{\mathrm{Pd}} \cdot \mathrm{Pd}\right]}_{\text {diatom PP }}
\end{aligned}
$$

$$
\begin{aligned}
& -\underbrace{\left[\theta_{\text {rem }} \cdot \theta_{\mathrm{Pn}} \cdot \phi \cdot \mathrm{G} \mu_{\mathrm{Pn}}\right]}_{\mu \text { zoo messy feeding, Pn }}-\underbrace{\left.\left[\theta_{\text {rem }} \cdot \phi \cdot \mathrm{G} \mu_{\mathrm{Dc}}\right)\right]}_{\mu_{\text {zoo messy feeding, Dc }}} \\
& -\underbrace{\left[\theta_{\text {rem }} \cdot \theta_{\mathrm{Pn}} \cdot \phi \cdot \mathrm{Gm}_{\mathrm{Pn}}\right]}_{\text {mzoo messy feeding, Pn }} \\
& -\underbrace{\left[\theta_{\text {rem }} \cdot \theta_{\mathrm{Pd}} \cdot \phi \cdot \mathrm{Gm}_{\mathrm{Pd}}\right]}_{\text {mzoo messy feeding, Pd }} \\
& -\underbrace{\left[\theta_{\mathrm{rem}} \cdot \theta_{\mathrm{Z} \mu} \cdot \phi \cdot \mathrm{Gm}_{\mathrm{Z} \mu}\right]}_{\text {mzoo messy feeding, } \mathrm{Z} \mu} \\
& -\underbrace{\left.\left[\theta_{\text {rem }} \cdot \phi \cdot \mathrm{Gm}_{\mathrm{Dc}}\right)\right]}_{\text {mzoo messy feeding, Dc }} \\
& -\underbrace{\left[\theta_{\text {rem }} \cdot R_{\mathrm{Z} \mu}\right]}_{\mu \text { zoo respiration }}-\underbrace{\left[\theta_{\text {rem }} \cdot R_{\mathrm{Zm}}\right]}_{\text {mzoo respiration }} \\
& -\underbrace{\left[\theta_{\text {rem }} \cdot \theta_{\mathrm{Pn}} \cdot \mathrm{M} 1_{\mathrm{Pn}}\right]}_{\text {non-diatom losses }}-\underbrace{\left[\theta_{\text {rem }} \cdot \theta_{\mathrm{Pd}} \cdot \mathrm{M} 1_{\mathrm{Pd}}\right]}_{\text {diatom losses }} \\
& -\underbrace{\left[\theta_{\text {rem }} \cdot \theta_{\mathrm{Z}} \mu \cdot \mathrm{M} 1_{\mathrm{Z} \mu}\right]}_{\mu_{\text {zoo losses }}}-\underbrace{\left[\theta_{\text {rem }} \cdot \theta_{\mathrm{Zm}} \cdot \mathrm{M}_{\mathrm{Zm}}\right]}_{\text {mzoo losses }} \\
& -\underbrace{\left[\theta_{\text {rem }} \cdot \mathbf{M}_{\mathrm{Dc}}\right]}_{\text {remin }}-\underbrace{\left[\theta_{\text {rem }} \cdot \mathrm{LD}_{\mathrm{C}}(k)\right]}_{\text {fast C remin }} \\
& -\underbrace{\left[\theta_{\text {nit }} \cdot \mathrm{BF}_{\mathrm{N}}\right]}_{\text {benthic remin }}-\underbrace{\left[\theta_{\text {rem }} \cdot \mathrm{BF}_{\mathrm{C}}\right]}_{\text {benthic remin }} \\
& +\underbrace{\left[A S F_{\mathrm{O}_{2}}\right]}_{\text {air-sea gas exchange }}
\end{aligned}
$$

The above equations are applied throughout the domain of the physical ocean model, without regard to horizontal or vertical position. This approach is inherited from MEDUSA-1.0 but differs from that of some other models (Popova et al., 2006) where different equations are applied in different volumes of the ocean to account, for instance, for photic and aphotic zones. Note that terms such as air-sea gas exchange, aeolian dust deposition and fluxes from the benthic submodel (see below) only apply in ocean grid cells in contact with either the atmosphere or benthos.

The following differential equations describe the benthic reservoirs of model currency that store and release biogenic material at the base of each water column in MEDUSA-2.0. As previously, each term is accompanied by a description of the process it describes.

$$
\begin{aligned}
\frac{\mathrm{dB}_{\mathrm{N}}}{\mathrm{d} t}= & +\underbrace{\left[w_{\mathrm{g}} \cdot \frac{\partial \mathrm{D}_{\mathrm{N}}}{\partial z}\right]}_{\text {slow } \mathrm{N} \text { deposit }}+\underbrace{\left[\mathrm{T}_{\mathrm{N}}(z)\right]}_{\text {fast } \mathrm{N} \text { deposit }} \\
& -\underbrace{\left[\lambda_{\mathrm{N}} \cdot \mathrm{B}_{\mathrm{N}}\right]}_{\text {benthic } \mathrm{N} \text { remin }}
\end{aligned}
$$




$$
\begin{aligned}
& \frac{\mathrm{dB}_{\mathrm{Si}}}{\mathrm{d} t}=+\underbrace{\left[\mathrm{T}_{\mathrm{Si}}(z)\right]}_{\text {fast Si deposit }}-\underbrace{\left[\lambda_{\mathrm{Si}} \cdot \mathrm{B}_{\mathrm{Si}}\right]}_{\text {benthic Si diss }} \\
& \frac{\mathrm{dB}_{\mathrm{C}}}{\mathrm{d} t}=+\underbrace{\left[w_{\mathrm{g}} \cdot \frac{\partial \mathrm{D}_{\mathrm{C}}}{\partial z}\right]}_{\text {slow } \mathrm{C} \text { deposit }}+\underbrace{\left[\mathrm{T}_{\mathrm{C}}(z)\right]}_{\text {fast } \mathrm{C} \text { deposit }} \\
&-\underbrace{\left[\lambda_{\mathrm{C}} \cdot \mathrm{B}_{\mathrm{C}}\right]}_{\text {benthic } \mathrm{C} \text { remin }} \\
& \frac{\mathrm{dB}_{\mathrm{Ca}}}{\mathrm{d} t}=+\underbrace{\left[\mathrm{T}_{\mathrm{Ca}}(z)\right]}_{\text {fast deposit }}-\underbrace{\left[\lambda_{\mathrm{Ca}} \cdot \mathrm{B}_{\mathrm{Ca}}\right]}_{\text {benthic } \mathrm{Ca} \text { diss }}
\end{aligned}
$$

Material enters these reservoirs as slow- and fast-sinking detritus, and remineralises (or dissolves) to DIN, iron, silicic acid, DIC and alkalinity. As with the rest of MEDUSA-2.0, iron is coupled via fixed stoichiometry to the nitrogen cycle and so is handled implicitly. Note that there is no horizontal communication between the benthic reservoirs in MEDUSA2.0.

Acknowledgements. AY, EEP, ACC and TRA gratefully acknowledge the financial support of the Natural Environmental Research Council (NERC), and this work was performed as part of the Regional Ocean Modelling project (ROAM; grant number NE/H017372/1) of the NERC UK Ocean Acidification research programme (UKOA). The work was part-funded by the European Union Seventh Framework Programme EURO-BASIN (FP7/20072013, ENV.2010.2.2.1-1; grant agreement no. 264933). DB was supported by the Joint DECC/Defra Met. Office Hadley Centre Climate Programme (GA01101), and work to perform HadGEM2ES simulations was supported by the EU-FP7 COMBINE project (grant number 226520).

The authors are particularly grateful to two anonymous referees for their thorough scrutiny of an earlier draft of this manuscript, as well as a series of suggested additions and amendments that have greatly improved its final form.

The authors are additionally grateful to the NEMO development team at NOC for their technical support throughout this work. In particular, the technical assistance of Beverly de Cuevas and Steven Alderson has been invaluable in the development and simulation of MEDUSA-2.0.

The carbonate chemistry scheme utilised by MEDUSA-2.0 to calculate, among other things, air-sea $\mathrm{CO}_{2}$ flux was supplied by Jerry Blackford (PML). The benthic reservoir scheme used here is based on a similar scheme developed, and supplied, by Momme Butenschön (PML).

The development of MEDUSA-2.0 greatly benefitted from discussions with a number of local and nonlocal colleagues, including: John Hemmings, Stephanie Henson, Adrian Martin and Ian Totterdell. The authors would also like to acknowledge the input of fellow participants in the UKOA programme.

Edited by: C. Klaas

\section{References}

Anderson, T. R.: Plankton functional type modelling: running before we can walk?, J. Plankton Res., 27, 1073-1081, doi:10.1093/plankt/fbi076, 2005.

Armstrong, R. A., Lee, C., Hedges, J. I., Honjo, S., and Wakeham, S. G.: A new, mechanistic model for organic carbon fluxes in the ocean: based on the quantitative association of POC with ballast minerals, Deep-Sea Res. II, 49, 219-236, 2002.

Behrenfeld, M. J. and Falkowski, P. G.: Photosynthetic rates derived from satellite-based chlorophyll concentration, Limnol. Oceanogr., 42, 1-20, 1997.

Behrenfeld, M. J., O’Malley, R. T., Siegel, D. A., McClain, C. R., Sarmiento, J. L., Feldman, G. C., Milligan, A.J., Falkowski, P. G., Letelier, R. M., and Boss, E. S.: Climate-driven trends in contemporary ocean productivity, Nature, 444, 752-755, 2006.

Bopp, L., Monfray, P., Aumont, O., Dufresne, J.-L., Le Treut, H., Madec, G., Terray, L., and Orr, J. C.: Potential impact of climate change on marine export production, Global Biogeochem. Cy., 15, 81-99, doi:10.1029/1999GB001256, 2001.

Bopp, L., Aumont, O., Cadule, P., Alvain, S., and Gehlen, M.: Response of diatoms distribution to global warming and potential implications: a global model study, Global Biogeochem. Cy., 32, L19606, doi:10.1029/2005GL023653, 2005.

Boyce, D. G., Lewis, M. R., and Worm, B.: Global phytoplankton decline over the past century, Nature, 466, 591-596, doi:10.1038/nature09268, 2010.

Boyce, D. G., Lewis, M. R., and Worm, B.: Boyce et al. reply, Nature, 472, E8-E9, doi:10.1038/nature09953, 2011.

Boyce, D. G., Lewis, M. R., and Worm, B.: Integrating global chlorophyll data from 1890 to 2010, Limnol. Oceanogr.Methods, 10, 840-852, doi:10.4319/lom.2012.10.840, 2012.

Buesseler, K. O., Lamborg, C. H., Boyd, P. W., Lam, P. J., Trull, T. W., Bidigare, R. R., Bishop, J. K. B., Casciotti, K. L., Dehairs, F., Elskens, M., Honda, M., Karl, D. M., Siegel, D. A., Silver, M. W., Steinberg, D. K., Valdes, J., Van Mooy, B., and Wilson, S.: Revisiting carbon flux through the ocean's twilight zone, Science, 316, 567-570, doi:10.1126/science.1137959, 2007.

Buitenhuis, E. T., de Baar, H. J. W., and Veldhuis, M. J. W.: Photosynthesis and calcification by Emiliania huxleyi (Prymnesiophyceae) as a function of inorganic carbon species, J. Phycol. 35, 9499, doi:10.1046/j.1529-8817.1999.3550949.x, 1999.

Caldeira, K. and Wickett, M. E.: Anthropogenic carbon and ocean pH, Nature, 425, 365-365, doi:10.1038/425365a, 2003.

Carr, M.-E., Friedrichs, M. A. M., Schmeltz, M., Aita, M. N., Antoine, D., Arrigo, K. R., Asanuma, I., Aumont, O., Barber, R., Behrenfeld, M., Bidigare, R., Buitenhuis, E. T., Campbell, J., Ciotti, A., Dierssen, H., Dowell, M., Dunne, J., Esaias, W., Gentili, B., Gregg, W., Groom, S., Hoepffner, N., Ishizaka, J., Kameda, T., Le Quéré, C., Lohrenz, S., Marra, J., Mélin, F., Moore, K., Morel, A., Reddy, T. E., Ryan, J., Scardi, M., Smyth, T., Turpie, K., Tilstone, G., Waters, K., and Yamanaka, Y.: A comparison of global estimates of marine primary production from ocean color, Deep-Sea Res. Pt. II, 53, 741770, 2006.

Collins, W. J., Bellouin, N., Doutriaux-Boucher, M., Gedney, N., Halloran, P., Hinton, T., Hughes, J., Jones, C. D., Joshi, M., Liddicoat, S., Martin, G., O’Connor, F., Rae, J., Senior, C., Sitch, S., Totterdell, I., Wiltshire, A., and Woodward, S.: Develop- 
ment and evaluation of an Earth-System model - HadGEM2, Geosci. Model Dev., 4, 1051-1075, doi:10.5194/gmd-4-10512011, 2011.

Cox, P. M., Betts, R. A., Jones, C. D., Spall, S. A., and Totterdell, I. J.: Acceleration of global warming due to carbon-cycle feedbacks in a coupled climate model, Nature, 408, 184-187, 2000.

Cunningham, S. A., Alderson, S. G., King, B. A., and Brandon, M. A.: Transport and variability of the Antarctic Circumpolar Current in Drake Passage, J. Geophys. Res., 108, 8084, doi:10.1029/2001JC001147, 2003.

Doney, S. C., Fabry, V. J., Feely, R. A., and Kleypas, J. A.: Ocean acidification: the other $\mathrm{CO}_{2}$ problem, Annu. Rev. Mar. Sci., 1, 169-192, 2009.

Doney, S. C., Ruckelshaus, M., Duffy, J. E., Barry, J. P., Chan, F., English, C. A., Galindo, H. M., Grebmeier, J. M., Hollowed, A. B., Knowlton, N., Polovina, J., Rabalais, N. N., Sydeman, W. J., and Talley, L. D.: Climate change impacts on marine ecosystems, Annu. Rev. Mar. Sci., 4, 11-37, doi:10.1146/annurev-marine-041911-111611, 2012.

DRAKKAR Group: Eddy-permitting Ocean Circulation Hindcasts of past decades, CLIVAR Exchanges, 42, 12, 8-10, 2007.

Dunne, J. P., Sarmiento, J. L., and Gnanadesikan, A.: A synthesis of global particle export from the surface ocean and cycling through the ocean interior and on the seafloor, Global Biogeochem. Cy., 21, GB4006, doi:10.1029/2006GB002907, 2007.

Dutkiewicz, S., Follows, M. J., and Parekh, P.: Interactions of the iron and phosphorus cycles: a three-dimensional model study, Global Biogeochem. Cy., 19, GB1021, doi:10.1029/2004GB002342, 2005.

Eppley, R. W.: Temperature and phytoplankton growth in the sea, Fish. Bull. Nat. Ocean. Atmos. Adm., 70, 1063-1085, 1972.

Fabry, V. J., Seibel, B. A., Feely, R. A., and Orr, J. C.: Impacts of ocean acidification on marine fauna and ecosystem processes, ICES J. Mar. Sci., 65, 414-432, 2008.

Fichefet, T. and Morales Maqueda, M. A.: Sensitivity of a global sea ice model to the treatment of ice thermodynamics and dynamics, J. Geophys. Res., 102, 12609-12646, 1997.

Gangst $\varnothing$, R., Joos, F., and Gehlen, M.: Sensitivity of pelagic calcification to ocean acidification, Biogeosciences, 8, 433-458, doi:10.5194/bg-8-433-2011, 2011.

Garcia, H. E., Locarnini, R. A., Boyer, T. P., Antonov, J. I., Baranova, O. K., Zweng, M. M., and Johnson, D. R.: World Ocean Atlas 2009, Volume 3: Dissolved Oxygen, Apparent Oxygen Utilization, and Oxygen Saturation, edited by: Levitus, S., NOAA Atlas NESDIS 70, US Government Printing Office, Washington DC, 344 pp., 2010a.

Garcia, H. E., Locarnini, R. A., Boyer, T. P., Antonov, J. I., Zweng, M. M., Baranova, O. K., and Johnson, D. R.: World Ocean Atlas 2009, Volume 4: Nutrients (phosphate, nitrate, silicate), edited by: Levitus, S., NOAA Atlas NESDIS 71, US Government Printing Office, Washington DC, 398 pp., 2010 b.

Gaspar, P., Grégoris, Y., and Lefevre, J.-M.: A simple eddy kinetic energy model for simulations of the oceanic vertical mixing tests at station papa and long-term upper ocean study site, J. Geophys. Res., 95, 16179-16193, 1990.

Gehlen, M., Gangst $\varnothing$, R., Schneider, B., Bopp, L., Aumont, O., and Ethe, C.: The fate of pelagic $\mathrm{CaCO}_{3}$ production in a high $\mathrm{CO}_{2}$ ocean: a model study, Biogeosciences, 4, 505-519, doi:10.5194/bg-4-505-2007, 2007.

Gnanadesikan, A., Slater, R. D., Gruber, N., and Sarmiento, J. L.: Oceanic vertical exchange and new production: a comparison between models and observations, Deep-Sea Res. II, 49, 363-401, 2002.

Gruber, N., Sarmiento, J. L., and Stocker, T. F.: An improved method for detecting anthropogenic $\mathrm{CO}_{2}$ in the oceans, Global Biogeochem. Cy., 10, 809-837, 1996.

Heinze, C.: Simulating oceanic $\mathrm{CaCO}_{3}$ export production in the greenhouse, Geophys. Res. Lett., 31, L16308, doi:10.1029/2004g1020613, 2004.

Henson, S. A., Sanders, R., and Madsen, E.: Global patterns in efficiency of particulate organic carbon export and transfer to the deep ocean, Global Biogeochem. Cy., 26, GB1028, doi:10.1029/2011GB004099, 2012.

Hibler, W. D.: A dynamic thermodynamic sea ice model, J. Phys. Oceanogr., 9, 815-846, 1979.

Hood, R. R., Laws, E. A., Armstrong, R. A., Bates, N. R., Brown, C. W., Carlson, C. A., Chai, F., Doney, S. C., Falkowski, P. G., Feely, R. A., Friedrichs, M. A. M., Landry, M. R., Moore, J. K., Nelson, D. M., Richardson, T. L., Salihoglu, B., Schartau, M., Toole, D. A., and Wiggert, J. D.: Pelagic functional group modeling: progress, challenges and prospects, Deep-Sea Res. II, 53, 459-512, 2006.

Houghton, J. T., Ding, Y., Griggs, D. J., Noguer, M., van der Linden, P. J., Dai, X., Maskell, K., and Johnson, C. A. (Eds.): Intergovernmental Panel on Climate Change 2001: the Scientific Basis, Cambridge University Press, Cambridge, UK, 881 pp., 2001.

Iglesias-Rodriguez, M. D., Halloran, P. R., Rickaby, R. E. M., Hall, I. R., Colmenero-Hidalgo, E., Gittins, J. R., Green, D. R. H., Tyrrell, T., Gibbs, S. J., von Dassow, P., Rehm, E., Armbrust, E. V., and Boessenkool, K. P.: Phytoplankton calcification in a High- $\mathrm{CO}_{2}$ world, Science, 320, 336-340, doi:10.1126/science.1154122, 2008.

Johns, T. C., Durman, C. F., Banks, H. T., Roberts, M. J., McLaren, A. J., Ridley, J. K., Senior, C. A., Williams, K. D., Jones, A., Rickard, G. J., Cusack, S., Ingram, W. J., Crucifix, M., Sexton, D. M. H., Joshi, M. M., Dong, D.-W., Spencer, H., Hill, R. S. R., Gregory, J. M., Keen, A. B., Pardaens, A. K., Lowe, J. A., Bodas-Salcedo, A., Stark, S., and Searl, Y.: The new Hadley Centre Climate Model (HadGEM1): evaluation of coupled simulations, J. Climate, 19, 1327-1353, 2006.

Jones, C. D., Hughes, J. K., Bellouin, N., Hardiman, S. C., Jones, G. S., Knight, J., Liddicoat, S., O’Connor, F. M., Andres, R. J., Bell, C., Boo, K.-O., Bozzo, A., Butchart, N., Cadule, P., Corbin, K. D., Doutriaux-Boucher, M., Friedlingstein, P., Gornall, J., Gray, L., Halloran, P. R., Hurtt, G., Ingram, W. J., Lamarque, J.-F., Law, R. M., Meinshausen, M., Osprey, S., Palin, E. J., Parsons Chini, L., Raddatz, T., Sanderson, M. G., Sellar, A. A., Schurer, A., Valdes, P., Wood, N., Woodward, S., Yoshioka, M., and Zerroukat, M.: The HadGEM2-ES implementation of CMIP5 centennial simulations, Geosci. Model Dev., 4, 543-570, doi:10.5194/gmd-4-543-2011, 2011.

Kelly-Gerreyn, B. A., Martin A. P., Tyrrell, T., and Somavilla, R.: Part 2. Calcification model user guide, in: MEECE EU Framework 7 project no. 212085: D2.2 Sub-model acidificationsensitive calcification rate, including user guide, edited by: Blackford, J., Artioli, Y., Kelly-Gerreyn, B. A., Martin A. P., Tyrrell, T., and Somavilla, R., 10-30, 2009. 
Key, R. M., Kozyr, A., Sabine, C. L., Lee, K., Wanninkhof, R., Bullister, J. L., Feely, R. A., Millero, F. J., Mordy, C., and Peng, T.-H.: A global ocean carbon climatology: results from Global Data Analysis Project (GLODAP), Global Biogeochem. Cy., 18, GB4031, doi:10.1029/2004GB002247, 2004.

Klaas, C. and Archer, D.: Association of sinking organic matter with various types of mineral ballast in the deep sea: implications for the rain ratio, Global Biogeochem. Cy., 16, 1116, doi:10.1029/2001GB001765, 2002.

Langer, G., Geisen, M., Baumann, K. H., Kläs, J., Riebesell, U., Thoms, S., and Young, J. R.: Species-specific responses of calcifying algae to changing seawater carbonate chemistry, Geochem. Geophy. Geosy., 7, Q09006, doi:10.1029/2005GC001227, 2006.

Le Quéré, C., Rödenbeck, C., Buitenhuis, E. T., Conway, T. J., Langenfelds, R., Gomez, A., Labuschagne, C., Ramonet, M., Nakazawa, T., Metzl, N., Gillett, N., and Heimann, M.: Saturation of the Southern Ocean $\mathrm{CO}_{2}$ sink due to climate change, Science, 316, 1735-1738, doi:10.1126/science.1136188, 2007.

Levitus, S., Antonov, J. I., Boyer, T. P., Garcia, H. E. and Locarnini, R. A.: EOF analysis of upper ocean heat content, 1956-2003, Geophys. Res. Lett., 32, L18607, doi:10.1029/2005GL023606, 2005.

Mackas, D. L.: Does blending of chlorophyll data bias temporal trend?, Nature: Brief communications arising, 472, E4-E5, doi:10.1038/nature09951, 2011.

Madec, G.: NEMO reference manual, ocean dynamic component: NEMO-OPA, Note du Pole de modélisation, Institut Pierre Simon Laplace, Technical Report 27, Note du pôle de modélisation, Institut Pierre Simmon Laplace, France, No. 27, ISSN No. 1288-1619, 2008.

Madec, G., Delecluse, P., Imbard, M., and Lévy, C.: OPA 8.1 ocean general circulation model reference manual, Note du Pole de modélisation, Institut Pierre Simon Laplace, France, Technical Report 11, 91 pp., 1998.

Martin, J. H., Knauer, G. A., Karl, D. M., and Broenkow, W. W.: VERTEX: carbon cycling in the northeastern Pacific, Deep-Sea Res. Pt. I, 34, 267-285, 1987.

McQuatters-Gollop, A., Reid, P. C., Edwards, M., Burkill, P. H., Castellani, C., Batten, S., Gieskes, W., Beare, D., Bidigare, R. R., Head, E., Johnson, R., Kahru, M., Koslow, J. A., and Pena, A.: Is there a decline in marine phytoplankton?, Nature: Brief communications arising, 472, E6-E7, doi:10.1038/nature09950, 2011.

Meijers, A. J. S., Shuckburgh, E., Bruneau, N., Sallee, J.-B., Bracegirdle, T. J., and Wang, Z.: Representation of the Antarctic circumpolar current in the CMIP5 climate models and future changes under warming scenarios, J. Geophys. Res., 117, C12008, doi:10.1029/2012JC008412, 2012.

Mongin, M., Nelson, D. M., Pondaven, P., and Tréguer, P.: Simulation of upper-ocean biogeochemistry with a flexible-composition phytoplankton model: $\mathrm{C}, \mathrm{N}$ and Si cycling and Fe limitation in the Southern Ocean, Deep-Sea Res. II, 53, 601-619, 2006.

Monterey, G. and Levitus, S.: Seasonal Variability of Mixed Layer Depth for the World Ocean, 96 pp. NOAA Atlas NESDIS 14, US Gov. Printing Office, Washington DC, 1997.

Moore, J. K. and Doney, S. C.: Iron availability limits the ocean nitrogen inventory stabilizing feedbacks between marine denitrification and nitrogen fixation, Global Biogeochem. Cy., 21, GB2001, doi:10.1029/2006GB002762, 2007.
Moore, J. K., Doney, S. C., Kleypas, J. A., Glover, D. M., and Fung, I. Y.: An intermediate complexity marine ecosystem model for the global domain, Deep-Sea Res. II, 49, 403-462, 2002.

Moore, J. K., Doney, S. C., and Lindsay, K.: Upper ocean ecosystem dynamics and iron cycling in a global threedimensional model, Global Biogeochem. Cy., 18, GB4028, doi:10.1029/2004GB002220, 2004.

Najjar, R. G., Jin, X., Louanchi, F., Aumont, O., Caldeira, K., Doney, S. C., Dutay, J.-C., Follows, M., Gruber, N., Joos, F., Lindsay, K., Maier-Reimer, E., Matear, R. J., Matsumoto, K., Monfray, P., Mouchet, A., Orr, J. C., Plattner, G.-K., Sarmiento, J. L., Schlitzer, R., Slater, R. D., Weirig, M.-F., Yamanaka, Y., and Yool, A.: Impact of circulation on export production, dissolved organic matter, and dissolved oxygen in the ocean: results from phase II of the Ocean Carbon-cycle Model Intercomparison Project (OCMIP-2), Global Biogeochem. Cy., 21, GB3007, doi:10.1029/2006GB002857, 2007.

Oka, A., Kato, S., and Hasumi, H.: Evaluating effect of ballast mineral on deep-ocean nutrient concentration by using an ocean general circulation model, Global Biogeochem. Cy., 22, GB3004, doi:10.1029/2007GB003067, 2008.

Orr, J. C., Fabry, V. J., Aumont, O., Bopp, L., Doney, S. C., Feely, R. A., Gnanadesikan, A., Gruber, N., Ishida, A., Joos, F., Key, R. M., Lindsay, K., Maier-Reimer, E., Matear, R., Monfray, P., Mouchet, A., Najjar, R. G., Plattner, G.-K., Rodgers, K. B., Sabine, C. L., Sarmiento, J. L., Schlitzer, R., Slater, R. D., Totterdell, I. J., Weirig, M.-F., Yamanaka, Y., and Yool, A.: Anthropogenic ocean acidification over the twentyfirst century and its impact on calcifying organisms, Nature, 437, 681-686, 2005.

Parekh, P., Follows, M. J., and Boyle, E. A.: Decoupling of iron and phosphate in the global ocean, Global Biogeochem. Cy., 19, GB2020, doi:10.1029/2004GB002280, 2005.

Passow, U. and De La Rocha, C. L.: Accumulation of mineral ballast on organic aggregates, Global Biogeochem. Cy., 20, GB1013, doi:10.1029/2005GB002579, 2006.

Popova, E. E., Coward, A. C., Nurser, G. A., de Cuevas, B., Fasham, M. J. R., and Anderson, T. R.: Mechanisms controlling primary and new production in a global ecosystem model - Part I: Validation of the biological simulation, Ocean Sci., 2, 249-266, doi:10.5194/os-2-249-2006, 2006.

Popova, E. E., Yool, A., Coward, A. C., and Anderson, T. R.: Regional variability of acidification in the Arctic: a sea of contrasts, Biogeosciences Discuss., 10, 2937-2965, doi:10.5194/bgd-102937-2013, 2013.

Raven, J. A., Caldeira, K., Elderfield, H., Hoegh-Guldberg, O., Liss, P., Riebesell, U., Shepherd, J., Turley, C., Watson, A., Heap, R., Banes, R., and Quinn, R.: Ocean Acidification Due to Increasing Atmospheric Carbon Dioxide, Royal Society of London, UK, 2005.

Ridgwell, A., Zondervan, I., Hargreaves, J. C., Bijma, J., and Lenton, T. M.: Assessing the potential long-term increase of oceanic fossil fuel $\mathrm{CO}_{2}$ uptake due to $\mathrm{CO}_{2}$-calcification feedback, Biogeosciences, 4, 481-492, doi:10.5194/bg-4-481-2007, 2007.

Riebesell, U., Zondervan, I., Rost, B., Tortell, P. D., Zeebe, R. E., and Morel, F. M. M.: Reduced calcification of marine plankton in response to increased atmospheric $\mathrm{CO}_{2}$, Nature, 407, 364-367, doi:10.1038/35030078, 2000. 
Riebesell, U., Schulz, K. G., Bellerby, R. G. J., Botros, M., Fritsche, P., Meyerhöfer, M., Neill, C., Nondal, G., Oschlies, A., Wohlers, J., and Zöllner, E.: Enhanced biological carbon consumption in a high $\mathrm{CO}_{2}$ ocean, Nature, 450, 545-548, doi:10.1038/nature06267, 2007.

Rykaczewski, R. and Dunne, J. P.: A measured look at ocean chlorophyll trends, Nature: Brief communications arising, 472, E5-E6, doi:10.1038/nature09952, 2011.

Schmittner, A., Oschlies, A., Matthews, H. D., and Galbraith, E. D.: Future changes in climate, ocean circulation, ecosystems, and biogeochemical cycling simulated for a business-as-usual $\mathrm{CO}_{2}$ emission scenario until year $4000 \mathrm{AD}$, Global Biogeochem. Cy., 22, GB1013, doi:10.1029/2007GB002953, 2008.

Semtner, A. J.: A model for the thermodynamic growth of sea ice in numerical investigation of climate, J. Phys. Oceanogr., 6, 376389, 1976.

Steinacher, M., Joos, F., Frölicher, T. L., Bopp, L., Cadule, P., Cocco, V., Doney, S. C., Gehlen, M., Lindsay, K., Moore, J. K., Schneider, B., and Segschneider, J.: Projected 21st century decrease in marine productivity: a multi-model analysis, Biogeosciences, 7, 979-1005, doi:10.5194/bg-7-979-2010, 2010.

Takahashi, T., Sutherland, S. C., Wanninkhof, R. Sweeney, C., Feely, R. A., Chipman, D. W., Hales, B., Friederich, G., Chavez, F., Sabine, C., Watson, A., Bakker, D. C. E., Schuster, U., Metzl, N., Yoshikawa-Inoue, H., Ishii, M. Midorikawa, T., Nojiri, Y., Kortzinger, A., Steinhoff, T., Hoppema, M., Olafsson, J., Arnarson, T. S., Tillbrook, B., Johannessen, T., Olsen, A., Bellerby, R., Wong, C. S., Delille, B., Bates, N. R., and de Baar, H. J. W.: Climatological mean and decade change in surface ocean $p \mathrm{CO}_{2}$, and net sea-air $\mathrm{CO}_{2}$ flux over the global oceans, Deep-Sea Res. Pt. II, 56, 554-577, doi:10.1016/j.dsr2.2008.12.009, 2009.

Taucher, J. and Oschlies, A.: Can we predict the direction of marine primary production change under global warming?, Geophys. Res. Lett., 38, L02603, doi:10.1029/2010GL045934, 2011. Timmermann, R., Goosse, H., Madec, G., Fichefet, T., Ethe, C., and Duliere, V.: On the representation of high latitude processes in the ORCA-LIM global coupled sea ice-ocean model, Ocean Model., 8, 175-201, doi:10.1016/j.ocemod.2003.12.009, 2005.

Tyrrell, T. and Taylor, A. H.: A modelling study of Emiliania huxleyi in the NE Atlantic, J. Mar. Syst., 9, 83-112, 1996.
Van der Waal, D. B., Verschoor, A. M., Verspagen, J. M. H., van Donk, E. and Huisman, J.: Climate-driven changes in the ecological stoichiometry of aquatic ecosystems, Front. Ecol. Environ., 8, 145-152, doi:10.1890/080178, 2010.

Van Minnen, J. G., Goldewijk, K. K., Stehfest, E., Eickhout, B., van Drecht, G., and Leemans, R.: The importance of three centuries of land-use change for the global and regional terrestrial carbon cycle, Climatic Change, 97, 123-144, 2009.

Volk, T. and Hoffert, M. I.: Ocean carbon pumps: analysis of relative strengths and efficiencies in ocean-driven atmospheric $\mathrm{CO}_{2}$ changes, Geophys. Monogr. Ser., 32, 99-110, doi:10.1029/GM032p0099, 1985.

Westberry, T., Behrenfeld, M. J., Siegel, D. A., and Boss, E.: Carbon-based primary productivity modeling with vertically resolved photoacclimation, Global Biogeochem. Cy., 22, GB2024, doi:10.1029/2007GB003078, 2008.

Wilson, J. D., Barker, S., and Ridgwell, A.: Assessment of the spatial variability in particulate organic matter and mineral sinking fluxes in the ocean interior: Implications for the ballast hypothesis, Global Biogeochem. Cy., 26, GB4011, doi:10.1029/2012GB004398, 2012.

Yool, A., Oschlies, A., Nurser, A. J. G., and Gruber, N.: A modelbased assessment of the TrOCA approach for estimating anthropogenic carbon in the ocean, Biogeosciences, 7, 723-751, doi:10.5194/bg-7-723-2010, 2010.

Yool, A., Popova, E. E., and Anderson, T. R.: Medusa-1.0: a new intermediate complexity plankton ecosystem model for the global domain, Geosci. Model Dev., 4, 381-417, doi:10.5194/gmd-4381-2011, 2011.

Yool, A., Popova, E. E., and Anderson, T. R.: MEDUSA-2.0: an intermediate complexity biogeochemical model of the marine carbon cycle for climate change and ocean acidification studies, Geosci. Model Dev. Discuss., 6, 1259-1365, doi:10.5194/gmdd6-1259-2013, 2013.

Zahariev, K., Christian, J. R., and Denman, K. L.: Preindustrial, historical, and fertilization simulations using a global ocean carbon model with new parameterizations of iron limitation, calcification, and $\mathrm{N}_{2}$ fixation, Prog. Oceanogr., 77, 56-82, 2008.

Zondervan, I., Zeebe, R. E., Rost, B., and Rieblesell, U.: Decreasing marine biogenic calcification: a negative feedback on rising atmospheric $\mathrm{CO}_{2}$, Global Biogeochem. Cy., 15, 507-516, doi:10.1029/2000GB001321, 2001. 